\title{
Professional Competition and Cooperation
}

TV News Coverage of Politicians' Visits to the Salon international de l'agriculture

Concurrences et coopérations professionnelles. La couverture des visites

politiques par les journalistes de télévision au Salon international de

l'agriculture

Competiciones y cooperaciones profesionales. La cobertura mediática de las visitas políticas al Salón internacional de la Agricultura por los periodistas de televisión

\section{Ivan Chupin and Pierre Mayance}

Translator. Delaina Haslam

\section{OpenEdition}

\section{Journals}

Electronic version

URL: http://journals.openedition.org/bssg/410

DOI: $10.4000 /$ bssg. 410

ISSN: 2490-9424

\section{Publisher}

Presses universitaires de Vincennes

\section{Electronic reference}

Ivan Chupin and Pierre Mayance, "Professional Competition and Cooperation", Biens Symboliques /

Symbolic Goods [Online], 6 | 2020, Online since 30 April 2020, connection on 04 March 2021. URL:

http://journals.openedition.org/bssg/410 ; DOI: https://doi.org/10.4000/bssg.410 


\section{Concurrences et coopérations professionnelles}

\section{La couverture des visites politiques par les journalistes de télévision au Salon international de l'agriculture}

\section{Professional Competition and Cooperation}

\author{
TV News Coverage of Politicians' \\ Visits to the Salon international de \\ l’agriculture
}

\author{
Ivan Chupin | Pierre Mayance \\ traduction | translation \\ Delaina Haslam
}

L'image de Nicolas Sarkozy à cheval en Camargue baladant dans un chariot un groupe de journalistes est venue résumer la domination du politique sur les journalistes en campagne. Elle a donné lieu à diverses dénonciations par des analystes politiques (Duhamel \& Field 2005). Or, s'en tenir à cette critique ne permet pas de bien saisir ce qu'il y a de plus structurel dans cette domination, qui est loin d'être univoque, ainsi que son enracinement dans des dispositifs techniques. C'est à l'aune de cette problématique que cet article se propose d'aborder la question de la co-construction de l'« événement médiatique » que constituent les déplacements politiques en analysant le cas des visites au Salon international de

l'agriculture (SIA).

Le Salon de l'agriculture s'est progressivement imposé comme un passage obligé pour les politiques chaque année, fin févrierdébut mars, à Paris ${ }^{1}$. La semaine du Salon est un événement

1. Voir encadré sur le terrain et la méthode.
The image of Nicolas Sarkozy on horseback in the Camargue trailed by a truckload of journalists has come to symbolize politics domination over journalists during an election campaign. This domination has attracted various accusations from political analysts (Duhamel \& Field 2005). Yet focusing on this criticism ignores the most structural aspect of this rather ambiguous domination, as well as its roots in technical equipment. This article aims to use this conundrum as a means to explore the collective endeavour to construct "media events," which such political outings constitute, by analysing the case of visits to the Salon international de l'agriculture (Paris International Agricultural Show, SIA).

The SIA has gradually established itself as an obligatory passage for politicians every year in Paris at the end of February/beginning of March ${ }^{1}$. The week of the SIA is a media event of which political

1. See the Field and Methodology section. 
pour les médias. Les visites font partie de cette actualité. Elles constituent de véritables rituels politiques couverts notamment par les journalistes télévisuels. Nous proposons ici d'interroger les conditions de production d'une information politique télévisuelle " en direct », dans un contexte de forte concurrence médiatique, de dépendance aux sources et d'importantes contraintes temporelles

et spatiales.

Nous étudions ici le travail journalistique dans le cadre de ces visites qui consistent, en pratique, en la gravitation d'un groupe d'individus autour des politiques. Ce groupe réunit l'entourage politique, les journalistes, mais aussi les services de sécurité et les membres du protocole du SIA responsables du bon déroulement de la visite (respect de l'agenda, orientation dans les allées du salon, etc.). Sa taille varie en fonction de l'importance du candidat et du contexte politique (élections). II existe en tant que «pool présidentiel » sous sa forme la plus institutionnalisée dans laquelle les journalistes doivent recevoir une accréditation spéciale de la part de la présidence pour couvrir l'événement.

Les études portant sur les communicants et les journalistes retiennent peu cet aspect (Legavre 2011 ; Kaciaf 2013) de l'organisation du travail journalistique lors des déplacements des politiques. Elles privilégient le décryptage des logiques du off the record (Legavre 1992), des stratégies et des cadrages (Gertslé \& Piar 2016) ou de la fabrique des petites phrases (Neveu 2009). S'il existe, dans la littérature de sciences sociales, plusieurs travaux sur les militaires et le caractère embedded des reporters (Charon \& Mercier 2004 ; Gatien 2009 ; Lindner 2009 ; Mac Laughin 2016), rares sont ceux qui portent sur ces formes d'encadrement visits are an integral part. They constitute veritable political rituals that are covered in particular by television news reporters. In this article we intend to analyse the conditions of production of a "live" television political news broadcast, within the context of fierce media competition, dependency on sources, and considerable temporal and spatial constraints.

This article will examine journalistic work within the context of these visits. In practice, the visits involve the formation of a group of individuals to surround the politicians. This group consists of the politician's entourage, journalists, and the security services and SIA staff responsible for the smooth running of the visit (keeping to the agenda, guiding the group around the show, and so on). The size of the group varies according to the prominence of the candidate and the significance of the political context, such as whether it is an election period. A "presidential pool" is the most institutionalized form of group for which journalists must obtain special accreditation from the presidency to cover the event.

Studies on communications staff and journalists pay little attention to this aspect (Legavre 2011; Kaciaf 2013) of the organization of journalistic work during politicians' visits. They focus on interpreting the "off the record" logic systems (Legavre 1992), the strategies and frameworks (Gertslé \& Piar 2016), or on creating soundbites (Neveu 2009). Although there are many examples in social science literature of studies into reporters in the military and the embedded nature of reporters (Charon \& Mercier 2004; Gatien 2009; Lindner 2009; Mac Laughin 2016), there are few that focus on this form of practical supervision in peace time ${ }^{2}$. This article

2. We only note certain rare exceptions on the topic of European institutions (Baisnée \& Marchetti 2006) 
pratique en temps civil ${ }^{2}$. Cet article envisage de combler pour partie cette lacune et participe aussi d'une sociologie politique des campagnes (Baamara et al. 2017) qui prend en compte le rôle des médias. La télévision est un espace de luttes mais également de complémentarités entre corps professionnels (Pasquier 2008 ; Mille 2016). Travailler sur un groupe de journalistes (organisé ou non en pool présidentiel) qui suit les politiques en s'intéressant aux pratiques permet ainsi de réactualiser des analyses sur l'économie de l'information en continu (Baisnée \& Marchetti 2002 ; Boczkowski 2004) dont la plupart des constats restent valides. L'article s'inscrit dans une tradition ethnographique de la fabrication de l'information très vivace dans la littérature anglo-saxonne des années 1970 (Tunstall 1971 ; Warner 1971 ; Tuchman 1973 ; Schlesinger 1978 ; Gans 1979) qui s'est depuis essoufflée malgré un appel à son renouveau dans les années 2000 (Cottle 2000). Par ailleurs, cette approche reste bien souvent cantonnée à une ethnographie de la rédaction (newsroom) même si elle intègre de plus en plus, hors des seuls journalistes, le rôle des divers intermédiaires de l'information comme les programmeurs, les infographistes à l'ère du numérique (Boczkowski 2015, 2017). Nous observons sur le terrain, en extérieur, les spécificités d'un travail journalistique « en direct » proche de l'instantanéité, soulignant ainsi la redéfinition de la contrainte du temps dans le métier qui participe à l'uniformisation des biens symboliques produits.

\section{Le terrain et la méthode}

Les journalistes sont étudiés dans le cadre du Salon international de l'agriculture (SIA) qui se tient chaque année fin février début mars à Paris. Cet événement réunit plus de six cent mille visiteurs venus observer les animaux et les produits

2. On ne note que quelques rares exceptions portant sur les institutions européennes (Baisnée \& Marchetti 2002). aims to go some way towards filling this gap and also to contribute to a political sociology of election campaigns (Baamara et al. 2017) that takes into account the role of the media. Television is a space for conflict, but also complementarity between professional bodies (Pasquier 2008; Mille 2016). Studying a group of journalists that follows politicians around (whether organized in a presidential pool or not) while focusing on the practice itself enables analysis on the economy of 24-hour news channels to be continuously updated (Baisnée \& Marchetti 2006; Boczkowski 2004); the majority of findings from which are still valid. The article subscribes to the ethnographic tradition of news production that was prevalent in English-language literature of the 1970s (Tunstall 1971; Warner 1971; Tuchman 1973; Schlesinger 1978; Gans 1979), but which has since waned despite a call for its revival in the 2000s (Cottle 2000). In addition, this approach is often limited to a newsroom ethnography, even if, increasingly it encompasses more than just journalists, to include the role of various information intermediaries in the digital era such as programmers and infographic designers (Boczkowski 2015, 2017). Our article observes the specifics of live, almost instantaneous external journalism work in the field, and in doing so highlights the redefining of time constraints in the profession that contribute to the uniformity of the symbolic goods

produced.

\section{Field and Methodology}

JournalistswereobservedinthecontextoftheSaloninternational de l'agriculture (SIA), which takes place annually in Paris at the end of February/beginning of March. More than 600,000 visitors attend the event at the porte de Versailles exhibition centre to see animals and sample regional produce. Every year many politicians attend the event. As a public relations tool, it provides a lobbying opportunity 
régionaux rassemblés Porte de Versailles. Chaque année de nombreux hommes et femmes politiques s'y rendent. Outil de relations publiques, il est un moment de lobbying pour les acteurs du secteur de l'agriculture et de l'agro-alimentaire. Sur le plan de la temporalité, nous avons enquêté dans une conjoncture de campagne présidentielle (2017), une conjoncture plus ordinaire (2018), et dans la période de pré-lancement d'une campagne européenne (2019). Lors des présidentielles de 2017, les principaux candidats sont François Fillon pour la droite (Les Républicains-LR), Marine Le Pen pour l'extrême-droite (Front National-FN) et JeanLuc Mélenchon pour la "gauche de la gauche » (France insoumise-FI). Emmanuel Macron (En marche, EM) qui s'imposera en définitive comme président a longtemps été considéré comme un candidat moins probable mais il a pu bénéficier de la sortie d'affaires disqualifiant durablement le candidat de la droite et de l'effondrement de la campagne de Benoît Hamon (Parti socialiste-PS). Sa visite au Salon le $1^{\text {er }}$ mars est ainsi moins suivie par les journalistes qui préfèrent couvrir celle de F. Fillon (Chupin \& Mayance 2018a). Le matériau mobilisé est ici ethnographique, ce qui constitue un apport car cette pratique de l'observation in situ reste peu utilisée par les spécialistes des médias (Tuntstall 1971; Siracusa 2001 ; Hubé 2008 ; Berthaut 2013 ; Christin 2014) et encore moins lorsqu'il s'agit de télévision (Siracusa 2001 ; Berthaut 2013). Si les visites présidentielles ont déjà pu être travaillées (Mariot 2007), la venue au Salon des politiques comme objet n'a pas encore été abordée. Sur le plan de la méthode, nous nous appuyons sur des notes de terrain prises tout le long des visites, ainsi que sur des photos, vidéos et sons réalisés par nos soins. Nous avons également complété ces notes par des entretiens, notamment avec les organisateurs et leurs services. Enfin, nous avons réalisé for actors in the agriculture and agribusiness sector. In terms of timescale, we focused on a presidential campaign (2017), ordinary circumstances (2018), and a pre-campaign period before the European elections (2019). In the 2017 presidential election campaign, the main candidates were François Fillon, former French Prime Minister, of the conservative Les Républicains (LR), Marine Le Pen of the far-right Front National (FN), and Jean-Luc Mélenchon of the far-left La France Insoumise (France Unbowed, FI). Emmanuel Macron of En Marche (On the Move, EM) who eventually became president, was for a large part of the campaign considered an unlikely candidate, but was able to take advantage of the scandal that resulted in the conservative candidate being disqualified and the collapse of the campaign of the Socialist Party candidate, Benoit Hamon. Macron's visit to the SIA on 1st March therefore received less interest from journalists who opted to cover the visit of François Fillon (Chupin \& Mayance 2018a). The data used are from ethnographic research, which serves as an asset given that this method of observation in situ remains little used by media specialists (Tuntstall 1971; Siracusa 2001; Hubé 2008; Berthaut 2013; Christin 2014) and even less so when it concerns television (Siracusa 2001; Berthaut 2013). While presidential campaign visits have previously been analysed (Mariot 2007), politicians' presence at the SIA has not been addressed. The methodology consisted of drawing on notes taken during visits as well as photographs, videos, and sound recordings that we captured. We have also added to these notes by conducting interviews primarily with organizers and their teams. Finally, we have carried out analysis of the main content derived from the visits on several major television channels (images/news reports), namely TF1, France 2, and 
une analyse des contenus principaux des produits qui en sont tirés sur les grandes chaînes de télévision (images/ reportages télévisés) que sont TF1, France 2 et $\mathrm{BFM}^{3}$. Si nous avons pu observer aussi d'autres médias (presse, radio) au travail, il s'agit ici d'analyser celui des journalistes de télévision.

Les journalistes de télévision se confrontent à un type particulier de visite. Le Salon de l'agriculture constitue en effet un rituel politique, dont l'importance est renforcée en période électorale. En relation avec les hommes et les femmes politiques, ils et elles participent à la co-production de cet événement. Les journalistes, tour à tour concurrents et partenaires, s'efforcent de fabriquer tant bien que mal des images et des sons en situation de contrainte. Ce cas nous renseigne sur les transformations de la couverture télévisuelle des visites politiques, sous le double prisme de l'irruption des chaînes d'information en continu et des stratégies déployées par les politiques.

\section{La visite politique au Salon de l'agriculture comme ritue}

\subsection{Une visite (en)cadrée}

Les visites politiques au Salon de l'agriculture, réussite de la profession agricole et des pouvoirs publics, mobilisent chaque année un nombre important de journalistes, surtout en période électorale. Ils ne sont pas les seuls à accompagner les politiques.

3. Pendant longtemps les chaînes de télévision sont, en France, peu nombreuses et principalement publiques. TF1, lancée en 1975 et privatisée en 1987, continue à obtenir les meilleures audiences. Renommée en 1992 France 2 reste sa principale concurrente. BFM est une chaîne d'information en continu privée. Elle est arrivée sur les ondes en 2005 avec la mise en place de la TNT (télévision numérique terrestre) qui offre gratuitement aujourd'hui vingt-sept chaînes.
$\mathrm{BFM}^{3}$. While we have also reviewed other media including press and radio, the focus here is on analysing the work of television journalists.

Television news reporters are faced with a particular type of visit. The SIA is indeed a political ritual whose significance is heightened during election campaigns. Journalists contribute to the co-production of the event alongside the politicians. The group of journalists, at once competitors and partners, strives to produce images and sound-bites as best they can in a constrained environment. From this we can see the transformation of the television coverage of political visits, through the dual lens of the emergence of twenty-four-hour news channels and the strategies used by politicians.

\section{Politicians' Visits to the Salon de l'Agriculture as Ritual}

\subsection{A Supervised and Directed Visit}

Every year, journalists flock to cover politicians' visits to the SIA-success story of the farming profession and the public authorities - and in even greater numbers during election periods. However, they are not the only ones to accompany politicians. This

3. Television in France has long been limited to a small number of public channels. TF1, launched in 1975 and privatized in 1987, continues to attract the largest audiences. Rebranded in 1992, France 2 is its main competitor BFM is a privately owned twenty-four-hour news channel, which started broadcasting in 2005 with the arrival of DTT (digital terrestrial television) and today offers twenty-seven free-to-air channels. 
On trouve aussi des soutiens, qu'ils ou elles soient élu·e.s ou non, des assistant $\cdot e \cdot s$, des communicant $\cdot e \cdot s$, ainsi que quelques militant·e.s qui, au Salon, tendent à rester discrets. Enfin, il y a le public qui cherche à se rapprocher des personnalités : il est encadré par les services de sécurité (publics et privés) et ceux du protocole, chargés de maintenir un espace autours des politiques tout en permettant aux médias d'être proches et de pouvoir travailler. Les visites sont donc le résultat d'une construction collective et sont fortement codifiées : elles constituent ainsi une sorte de rituel.

Du côté des journalistes, le caractère très « grand public » du SIA mobilise un large éventail de médias (près de deux mille accrédité $\cdot \cdot \cdot s$ ) : journalistes de presse écrite, de radio, de télévision et photographes pour des médias tant locaux qu'internationaux, tant politiques que généralistes. Le public est la plupart du temps de facto maintenu à distance par le groupe qui suit les politiques dans des allées du Salon. Les visiteurs veulent parfois savoir/voir qui ils ou elles sont (le groupe qui entoure les politiques faisant écran) et demandent parfois à prendre une photo. L'organisation du Salon (Centre national des expositions et concours agricoles/ CENECA) chapote ce dispositif. Ses services dressent une liste des personnes éligibles au protocole. Le président de la République, le Premier ministre, les anciens présidents et Premiers ministres en font partie. C'est le cas aussi des politiques nationaux de premier plan, ainsi que les chefffe-s d'État étranger·ère-s et des ambassadeur.rice.s. Cette liste comprenait, en 2017, cinquante personnes ${ }^{4}$. S'ensuit un échange entre l'équipe du «VIP » et les services du protocole. Ensemble, ils décident du parcours emprunté au Salon, des allées et stands qu'ils entendent visiter.

4. Entretien avec Jean-Luc Poulain, directeur du CENECA, le 4 mars 2017. is where we find the political entourage: aides, supportive fellow politicians who are elected or not, assistants, communications staff, as well as a few party activists who tend to be discreet at the Salon. Finally, there is the general public who want to approach the politicians. Politicians are accompanied by public and private security personnel and event security staff, who are responsible for maintaining a protected space around the politicians while at the same time enabling the media to gain access to them to be able to do their jobs. The planning and execution of the visits are therefore collective endeavours, and as a result the visits are highly codified, thus constituting a sort of ritual.

From a journalistic perspective, the fact that the SIA is open to the general public means that it attracts a large media presence (up to 2,000 accredited individuals), with the press, radio and television, and photographers for both domestic and international media outlets all represented. As well as being covered by political journalists, politicians' visits are also covered by general-interest reporters. Members of the public are largely de facto kept at a distance from the group that follows the politicians around the event. Occasionally visitors want to know or see who the politicians are that the group is shielding and may request to take a photo. The event organizers, CENECA (Centre national des expositions et concours agricoles, National Centre for Agricultural Shows and Competitions) oversee the coordination of the visits. They draw up a list of eligible individuals that is sent to the event management team. The president, the prime minister, and former presidents and prime ministers are all included, as are high-profile national politicians and foreign heads of state and ambassadors. In 2017 this list consisted of fifty people ${ }^{4}$. A discussion then takes place between the VIP team and the event management. Together they

4. Interview with Jean-Luc Poulain, director of CENECA, 4 March 2017 
Le protocole propose un parcours «type » et répond aux attentes des entourages des politiques. Le trajet est parfois contrôlé par les services de la protection des personnalités et donc amendé pour des raisons de sécurité. Les organisateurs fournissent un dispositif privé de protection rapprochée, notamment doté d'un ou plusieurs "physios": souvent recrutés parmi les anciens agents des forces de l'ordre, ceux-ci travaillent à côté des personnes du protocole dont la mission consiste aussi à guider le visiteur dans les allées du Salon. Le protocole ne communique pas aux journalistes les informations concernant les heures d'arrivée, de départ ou encore le parcours. Ce sont les responsables de la communication des politiques qui donnent rendez-vous (et parfois le programme) aux médias, souvent seulement la veille de la venue au SIA. IIs communiquent ensuite en temps réel avec les journalistes tout au long du déroulement de l'événement.

Concernant le parcours, il est le résultat d'une logique double : fournir des images mais aussi permettre les rencontres avec le secteur agricole ${ }^{5}$. Loin des représentations médiatiques qui en sont données, le Salon international de l'agriculture est aussi une opportunité pour les hommes politiques d'échanger concrètement avec divers groupes d'intérêts. Pour la plupart d'entre eux, rencontrer ces lobbies et ces syndicats constitue la principale activité en termes de temps. Leur parcours les amène à rencontrer généralement une dizaine d'organisations, des représentants des filières ${ }^{6}$ aux syndicats généralistes ${ }^{7}$, pour des échanges qui

5. Concernant ces deux logiques, voir Chupin \& Mayance $2018 \mathrm{~b}$.

6. A travers leurs interprofessions : le Centre national interprofessionnel de l'économie laitière (CNIEL), l'Office national interprofessionnel du bétail et des viandes (ONIBEV), l'Interprofession de la filière des Fruits et Légumes Frais (Interfel) ou encore I'Interprofession nationale porcine (Inaporc), mais aussi les Brasseurs de France ou les Vignerons indépendants.

7. La Fédération nationale des syndicats d'exploitants agricoles (FNSEA), les Jeunes agriculteurs (JA), la Coordination rurale (CR), la Confédération paysanne et le Mouvement de défense des exploitants familiaux (Modef). decide on the route around the SIA, the aisles and stands that they want to visit. The event management team suggests a typical route, responding to the expectations of the politicians' entourages. The route is sometimes inspected by the individuals' protection officers and may consequently be amended for security reasons. The organizers supply privately arranged close protection, with one or more "bouncers." Often ex-police officers, they work alongside the event's own security staff whose role also includes guiding the visitor around the event. The event management does not share information regarding arrival and departure times or planned routes with journalists. This is the responsibility of the politician's communications staff who give a briefing (and occasionally the full programme) to the media, often only the day before the visit to the SIA. They then stay in constant communication with the journalists in real time throughout the event itself.

The rationale behind the chosen route around the event is twofold: it must provide photo opportunities and also enable interaction with the agricultural sector ${ }^{5}$. Far from what media representations may suggest, the SIA is also a chance for politicians to interact in person with a diverse range of interest groups. For the majority of politicians, meeting these lobby groups and trade unions constitutes the main activity in terms of time. Their route around the event generally leads them to meet ten or so organizations, from industry representatives $^{6}$ to general trade unions ${ }^{7}$, for discussions that

5. Regarding these two approaches, see (Chupin \& Mayance 2018b).

6. Through their respective industry associations: the national dairy industry council (CNIEL), the national bureau for the meat and livestock industry (ONIBEV), the fresh fruit and vegetables industry body (INTERFEL), and the national pig association (INAPORC), as well as the brewers association and the national winemakers federation.

7. France's main farming union, FNSEA, the young farmers' union, Jeunes agriculteurs, the Coordination rurale union, the Confédération paysanne union, and the movement for family farming, MODEF. 
durent souvent plus de vingt minutes, la plupart du temps à huis$\operatorname{clos}^{8}$. L'accès des journalistes n'y est pas autorisé. Ils et elles ne traitent pas des visites off qui pourtant sont autant d'éléments ${ }^{9}$ de distinction des stratégies des politiques. Ils jouent en revanche le jeu de la mise en scène des rituels.

\subsection{Images attendues et traitement ordinaire de la politique}

La relative similitude des parcours et l'encadrement par le protocole participent de l'uniformisation des biens produits. La visite au Salon sert de sondage grandeur nature pour les journalistes qui leur permet d'intervenir dans le débat public à l'instar des sondages ordinaires (Champagne 1990, Kaciaf 2013). Ainsi, lors de la visite de Marine Le Pen au Salon en 2017, il est rappelé par le présentateur de TF1 qui lance ce sujet télévisé que " son père ${ }^{10}$ avait été hué en 2002 » alors que l'accueil de "Marine ${ }^{11}$ »

8. Les syndicats agricoles sont un peu plus « ouverts » sur le Salon public Seule la FNSEA dispose de deux salons, dont l'un sur la terrasse du toit du stand où davantage de personnes peuvent s'entretenir, autour d'une table d'une dizaine de places.

9. Si la plupart des parcours se ressemblent, on peut néanmoins noter des différences (comme par exemple rencontrer la Confédération Paysanne ou non). C'est une manière pour les politiques d'envoyer des signaux sur les modèles d'agriculture qu'ils défendent dans leurs programmes ou sur des clientèles électorales qu'ils entendent plus spécialement cibler.

10. Son père est Jean-Marie Le Pen, qui a été président du Front national (FN) à partir de 1972 et jusqu'à l'élection de sa fille en 2011.

11. Marine Le Pen est parfois dénommée par son seul prénom, notammen par ses soutiens et électeurs. Cet usage a plusieurs effets : cela produit une certaine proximité et familiarité tout en passant sous silence le nom de Le Pen, qui joue comme un stigmate. À partir des législatives de 2012, le Front national s'affiche dans le cadre d'une coalition plus large au sein du Rassemblement bleu Marine (dissous après « l'échec » des présidentielles de 2017). En 2018, le FN change de nom et devient le Rassemblement national $(\mathrm{RN})$. often last more than twenty minutes, with the majority of time spent behind closed doors ${ }^{8}$. Journalists are not permitted access to these private visits, which clearly are all part ${ }^{9}$ of politicians' strategies. Instead they play along with the game of enacting the ritual.

\subsection{Expected Images and Ordinary Treatment of Politicians}

The relative similarity of the routes and the supervision by the event management contributes to a uniformity in the content produced. The visit to the SIA serves as a large-scale opinion poll for journalists, allowing them to enter into the public debate like any other opinion poll (Champagne 1990, Kaciaf 2013). Thus, during Marine Le Pen's visit to the SIA in 2017, the TF1 presenter reminded us that "her father ${ }^{10}$ was booed in 2002" while

8. Farmers' unions are generally a little more "open" at the public-facing SIA The FNSEA is the only union that has two rooms, one of which is on the roof terrace where larger numbers of people can sit and have discussions around a table of ten or so places.

9. While the majority of routes around the SIA are very similar, there are nevertheless notable differences, such as, for example, whether or not there is a meeting with the Confédération paysanne left-leaning farming union. This is a way for politicians to send out a signal on which agricultural models they support in their campaigns or which part of the electorate they specifically want to target.

10. Her father is Jean-Marie Le Pen who was president of the Front National (FN) from 1972 until 2011 when he was replaced by his daughter. 
cette année aurait traduit davantage de « chaleur » de la part des agriculteurs $^{12}$. De la même manière, lors du sujet relatant la visite du président de la République François Hollande - qui ouvre le Salon en 2017 -, le journaliste précise : « L'an dernier François Hollande avait été hué puis chahuté dans les allées du Salon de l'agriculture. Ce matin l'accueil est plus souriant, selfies et encouragements ${ }^{13}$. " Les journalistes peuvent ainsi se mettre en position d'évaluateur de la réussite ou non de la visite, et donc du soutien ou non supposé du secteur agricole et du peuple français croisé dans les allées du Salon. On retrouve aussi régulièrement dans les sujets télévisés les "petites phrases " des politiques. Par exemple, M. Le Pen se fait reprendre dans les journaux lors d'un échange avec un agriculteur où elle affirme qu'« on a toujours mieux commercé quand il n'y avait pas l'Union européenne ». On retrouve cette affirmation dans les deux journaux télévisés de TF 1

et France $2^{14}$

Le traitement médiatique de la venue des politiques est également représentatif d'un traitement journalistique centré sur le jeu au détriment des enjeux puisque les politiques se voient mis en scène exclusivement dans des plans stéréotypés, tantôt en contact avec des animaux, tantôt en train de manger des produits régionaux. $\mathrm{Ce}$ type de mise en scène médiatique contribue à renforcer l'image de proximité avec le grand public et les éleveurs que les politiques peuvent renvoyer d'eux. En sujets télévisés, les politiques sont souvent filmés dans le hall 1 du parc des expositions de la porte de Versailles au contact de certains animaux, notamment des

12. Journal télévisé, 20 heures de TF1, le 28 février 2017.

13. Journal télévisé, 13 heures de TF1, le 25 février 2017

14. Journaux télévisés, 20 heures de France 2 et TF1, le 28 février 2017
"Marine's ${ }^{11 "}$ reception from farmers this year was much "warmer ${ }^{12 "}$. In the same manner, while reporting on the visit of the president François Hollande-who opened the SIA in 2017-the journalist explained: "Last year François Hollande was booed and then heckled at the Salon de l'agriculture. This morning the welcome is more smiles, selfies, and encouragement ${ }^{13}$ ". Journalists can thus assume a position of evaluating how successful the visits are and consequently deducing the level of support for the politician from the agricultural sector or the members of the French people they have passed in the halls of the event. We also see regular use of politicians' "catch phrases" in television news items. For example, an exchange between Marine Le Pen and a farmer was highlighted in a news report, with the politician stating that "business was always better before the European Union." This statement was found in both television news broadcasts on TF1 and France $2^{14}$

Media coverage of politicians' visits is also representative of a journalistic approach that focuses on the game elements to the detriment of the issues at hand, as the politicians are seen exclusively in stage-managed, stereotypical shots showing them with animals or with mouths full of regional products. This type of media staging reinforces the image of familiarity that politicians can

11. Marine Le Pen is often referred to simply by her first name, particularly by her supporters and voters. This usage has several effects: it creates a proximity and familiarity while at the same time silencing the Le Pen name, which is stigmatized. Following the legislative elections in 2012, the Front National presented itself in the framework of a wider coalition within the Rassemblement bleu Marine (dissolved after "failure" in the 2017 presidential election). In 2018 the FN changed its name to Rassemblement National (National Rally).

12. TF1 News, 20:00, 28 February 2017.

13. TF1 News, 13:00, 25 February 2017.

14. TF1 News and France 2 News, 20:00, 28 February 2017. 
vaches $^{15}$. Le sujet ${ }^{16}$ sur la visite du président F. Hollande s'ouvre par un plan-séquence dans l'enclos de la vache-égérie ${ }^{17}$ qui fait office de lieu très institutionnalisé de prise de vue pour les photographes. Le président plaisante à voix haute avec les journalistes et les photographes qui sont hors de l'enclos en leur demandant s'« ils ont eu la vache ${ }^{18}$ ». M. Le Pen n'échappe pas à cette mise en scène d'elle-même au contact des animaux et de la nature puisque, dans le sujet qui lui est consacré sur TF1 en 2017, on la voit en train de discuter de la politique agricole européenne avec deux éleveurs bovins pris au milieu de leurs bêtes. Sur France 2, on la retrouve également en train de poser peu de temps après son arrivée dans l'enclos de la vache-égérie en compagnie de Gilbert Collard ${ }^{19}$ et de Florian Philippot ${ }^{20}$. Quand ils ne discutent pas avec des agriculteurs, les politiques apparaissent souvent en train de déguster des produits du terroir (fromage, saucisson). On retrouve ce type de cadres routiniers sur TF1 pour la visite de F. Hollande mais aussi pour celle du premier ministre Bernard Cazeneuve. Le Salon donne lieu à la mise en scène du corps des politiques dont le

15. Plus rares sont les politiques qui se font filmer avec des chiens, avec des chevaux ou encore des lapins présents dans deux autres autre halls.

16. Journal télévisé, 20 heures de France 2 , le 25 février 2017.

17. À chaque édition est désormais associée une vache-égérie qui perme d' « incarner » le Salon dans la communication à destination du grand public. Cette vache n'est pas prise au hasard: le choix répond à divers critères de valorisation de telle ou telle race qui font varier également la taille des exploitations.

18. Journal télévisé, 13 heures de TF1, le 25 février 2017.

19. Avocat engagé en politique, Gilbert Collard se rapproche du Front nationa dans les années 2010 et participe de la stratégie de " dédiabolisation » du parti d'extrême droite engagé par Marine Le Pen et son entourage. II est élu député en 2012 et réélu en 2017.

20. Proche de M. Le Pen à la faveur de son rôle dans sa campagne présidentielle de 2012, Florian Philippot est poussé au départ du FN fin 2017 après création de son propre mouvement, Les Patriotes, et suite à des tensions au sein de la direction du parti. create of themselves in these types of outings with the general public and farmers. In the televised news reports, politicians are often filmed in the first hall of the porte de Versailles exhibition centre where they come into contact with some of the animals, particularly cows ${ }^{15}$. The news item ${ }^{16}$ on the visit of President François Hollande opened with a long take inside the enclosure of the mascot $\operatorname{cow}^{17}$, a highly institutionalised shooting location for the photographers. Hollande can be heard joking with the journalists and photographers who were outside the enclosure, asking them if they had "caught the cow ${ }^{18}$ ". Marine Le Pen also could not avoid this routine with animals and nature as in the TF1 news report on her visit in 2017 we see her discussing European agricultural policy with two cattle breeders, while stood in the middle of their animals. On France 2 we saw her, shortly after her arrival, posing in the enclosure of the mascot cow in the company of Gilbert Collard $^{19}$ and Florian Philippot ${ }^{20}$. When they are not speaking to farmers, politicians often appear sampling regional products such as cheese and saucisson. We find this type of routine shot on TF1

15. It is rare for politicians to be filmed with dogs, horses, or even rabbits in the two other exhibition halls.

16. France 2 News, 20:00, 25 February 2017.

17. The SIA now has an annual mascot cow, which is the principal visual element of the event's marketing to the general public. This cow is not randomly selected, but instead must meet a range of criteria tailored to different breeds and different sized farm holdings.

18. TF1 News, 13:00, 25 February 2017.

19. A politically engaged lawyer, Gilbert Collard joined forces with the Fron National from 2010 onwards and contributed to the far-right party's strategy of dédiabolisation or "de-demonization", begun by Marine Le Pen and he entourage. He was elected as a member of parliament in 2012 and re-elected in 2017.

20. A close supporter of M. Le Pen during her presidential election campaign in 2012, Florian Philippot was pushed out of the FN at the end of 2017 after creating his own movement Les Patriotes and amid tensions within the party's leadership. 
cas de l'ancien président Jacques Chirac, ingurgitant de nombreux aliments et boissons alcoolisés, constitue sans doute l'exemple le plus archétypal. Ils doivent montrer leur résistance et leur grande capacité à ingurgiter des produits de plusieurs terroirs, ce qui renvoie à une forme de générosité et à un amour presque charnel de leur pays (et de son patrimoine culinaire) dans l'ensemble de ses composantes.

\section{Les visites, quels enjeux pour les journalistes de la télévision?}

\subsection{Un sale boulot ? La concurrence des corps} pour l'accès à l'image

Toute visite suscite la constitution d'un important groupe de journalistes qui suivent les politiques, eux-mêmes protégés au sein d'une bulle par leur sécurité rapprochée. Si bien que lorsqu'ils se déplacent, c'est un groupe de quelques personnes à presque une centaine qui doit se mouvoir. Ainsi, en 2017, la visite de M. Le Pen mobilise de très nombreux journalistes dont certains travaillent pour les télévisions étrangères : ZDF, le premier canal russe, l'agence Reuters, la NHK (Japon), la Radio Popolare (Italie), etc. Dans de telles conditions, le tournage devient vite une épreuve, notamment pour les journalistes reporters d'images (JRI) ${ }^{21}$ qui doivent jouer des coudes pour avoir une image que personne ne peut leur garantir dans cette concurrence ouverte. Pendant cette visite, un journaliste se plaint que « personne ne peut bosser », un JRI de TF1 face à la cohue constate que « le boulot, en général,

21. Le JRI dispose en France d'une carte de presse et est donc un journaliste à part entière. Chargé de la prise d'images et du son (parfois épaulé par un perchiste), il peut aussi être amené à assurer le montage des sujets. II est souvent accompagné par un rédacteur-reporter qui pose les questions et apparaît à l'écran. for the visit of François Hollande and also for the prime minister, Bernard Cazeneuve. The SIA presents a performative setting for politicians' bodies. Scenes of the former president Jacques Chirac devouring various food products and alcohol drinks is by far the most archetypal example. They must demonstrate their endurance and a large capacity for consuming products from various terroirs, to embody a kind generosity and an almost carnal love for their country (and its culinary heritage) in all its forms.

\section{Political Visits to the SIA: What Do They Imply for Broadcast Journalists?}

\subsection{Dirty Work? Bodies Competing to Get the Shot}

A visit to the SIA requires the formation of a large group of journalists to follow the politicians around, who are themselves kept within the protective bubble of their security detail. When they move, a group of anything from a few to almost a hundred people moves with them. And so, in 2017, Marine Le Pen's visit attracted a large number of journalists, including some working for foreign television channels: ZDF (Germany), Russia's main channel, Reuters news agency, NHK (Japan), Radio Popolare (Italy), etc. In such conditions, filming quickly becomes a test, especially for broadcast journalists (journalistes reporters d'images or JRIs, in French) ${ }^{21}$ who must jostle to get images that no one can guarantee them in this free-for-all. During this visit, one journalist complains that: "No one can work," a JRI from the TF1 channel said in response to the mayhem: "In general it's our job to get images, but here we're not

21. JRIs have press cards and are therefore journalists in their own right. They are in charge of recording images and sound (sometimes supported by a boom operator) and can also be brought in to help with scene assembly and editing. They are often accompanied by a reporter who asks the questions and appears on screen 
c'est de faire de l'image », mais qu'« ici, on n'est pas journaliste télé ». Ils parlent entre collègues pendant que d'autres journalistes télévisuels démontent un panneau pour se positionner plus haut que les autres afin de pouvoir tourner une image ${ }^{22}$. Ils ne sont pas les seuls à suivre les politiques, ils sont en concurrence pour occuper un même espace avec d'autres journalistes ainsi que d'autres agents. En effet, impossible de suivre la visite si on se trouve à plus de quelques mètres du politique : on ne capte ni visuel, ni son. Tout type de médias (télévision, radios, presse écrite, en ligne) cherche à obtenir des informations, soit par un système de collectivisation de la prise de son, soit par une présence au plus proche, mais qui les met en concurrence avec les cameramen de télévision. Ceux-ci doivent d'ailleurs depuis quelques années composer avec d'autres agents qui cherchent à capter des images qui étaient jusqu'alors leur monopole. Des pure players ${ }^{23}$ sont apparus. JRI, ils produisent des reportages diffusés sur YouTube dont les images sont revendues par leur agence aux chaînes de télévision (notamment étrangères) intéressées. C'est aussi le cas pour les web TV, ou les blogueurs. Les journalistes de radio ou de presse écrite sont de plus en plus poussés par leurs rédactions à réaliser aussi de courts formats vidéo. La prise d'image et de son même est ainsi devenue encore plus concurrentielle. Lors des visites alternent des moments de concurrence forte pour obtenir et tenir une place permettant une bonne prise de vue et des moments de relative stabilité quand les politiques restent statiques et échangent avec des profanes ou répondent aux journalistes. L'enjeu, pour chacun des cameramen et des perchistes, est de prendre et de tenir sa place au plus près du candidat. La production de belles images vise à correspondre aux visuels attendus du rituel

22. Note de terrain, visite de M. Le Pen, 28 février 2017

23. On entend par pure player, dans le domaine de l'information, une entreprise qui est à $100 \%$ en ligne et ne diffuse son contenu que sur internet (comme, en France, le cas de Mediapart)
TV journalists." They are talking amongst themselves while other television journalists are dismantling a sign which will enable them to climb up higher than the others to film the shot ${ }^{22}$. They are not the only ones following the politicians; they vie with other journalists and other agents for the same spot. Indeed, it is impossible to follow the visit unless you are within a few metres of the politician: neither visuals nor sound can be recorded. A mix of journalists of all types of media (television, radio, print and online journalists) attempt to gain information, either via a system of collectivisation to record sound, or by getting closest, which puts them in competition with the television camera operators. The latter have, besides, for several years had to deal with other agents seeking to get images, which up until then had been their monopoly. "Pure players ${ }^{23}$ " have appeared on the scene. JRIs produce stories that are posted on YouTube, the images of which are resold by their agency to interested television channels (foreign channels in particular). This is also the case for online television broadcasters and bloggers. And radio and print journalists are increasingly driven by their editors to also produce short video formats. Image and sound recording have similarly become even more competitive.

The visits alternate between moments of fierce competition to gain and maintain a spot with a good view, and moments of relative stability when the politicians stay in one place to meet the public and answer journalists' questions. It is key for the camera and boom operators to get and maintain a spot as near as possible to the candidate. Producing good images means meeting the expected visual requirements of the visit ritual, but also material aspects (framing, sound quality, etc.). Amidst the chaos, it is the JRIs who are most put to the test physically. They must obtain their own

22. Field notes, M. Le Pen's visit, 28 February 2017.

23. In the field of information technology pure player refers to a company that is 100 per cent online and only publishes on the internet (such is the case for Mediapart in France) 
de la visite, mais aussi à des éléments matériels (cadrage, qualité du son, etc.). Dans cette cohue, le JRI est celui dont le corps est le plus soumis à l'épreuve : il doit obtenir des images propres, c'està-dire avoir un angle direct sur les politiques et leurs interactions. Les perchistes sont responsables du son. Ils disposent de perches de plus de trois mètres vingt (standard). Positionnés derrières les cameramen, ils sont essentiels pour écouter ce qui se passe. Plus ils sont nombreux, plus ils doivent tenir la perche à bout de bras à distance. La lutte entre cameramen pour les places au plus proche des politiques se rejoue, à quelques mètres, entre perchistes avec cet enjeu redoutable : si une image peut être coupée ou remontée, la prise de son s'avère, elle, inexploitable si la phrase et les échanges sont incomplets. On assiste parfois à des combats de perches pour le meilleur positionnement dans cet espace limité tant pour la prise de son que d'images. Pour fournir un exemple de l'intensité de cette présence journalistique, on peut compter plus d'une vingtaine de perches pour la visite de M. Le Pen comme candidate, positionnées à la sortie de l'enclos de la vache égérie du Salon le 28 février 2017 à 9 h43 [voir illustration 1]. Dans cet exemple, ne sont pas pris en compte les JRI qui disposent d'un micro positionné directement sur leur caméra et ne sont pas accompagnés d'un perchiste. La prise de son est essentielle pour les journalistes rédacteurs. Dans l'impossibilité d'écouter les échanges s'ils ne sont pas positionnés à un ou deux mètres des politiques, la perche ou le micro constitue un relais qui leur permet d'élaborer leur commentaire. Ce même mécanisme joue pour les journalistes de radio qui ne peuvent pas, autrement, commenter les propos des politiques. La couverture médiatique d'une visite constitue une épreuve véritablement physique, renforcée en période électorale. Ces visites durent le plus souvent sept heures, voire 14 heures et 40 minutes pour la visite présidentielle record d'E. Macron en 2019. Les équipes télévisuelles cherchent alors à être relevées, mais restent bien souvent mobilisées la majeure partie du temps. images, that is to say have a direct angle on the politicians and their interactions. The boom operators are responsible for the sound. They have booms of more than $3 \mathrm{~m} 20$ long (which is standard). Positioned behind the camera operators, they are essential to be able to hear what is going on. The more boom operators there are, the more they have to keep their boom at arm's length. The struggle between camera operators for the spaces closest to the politicians is replayed between the boom operators a few metres away. This is all the more important as in the case of sound, if a phrase or entire conversations are incomplete they can't be used, whereas an image may always be edited or cut. Fights between booms for the best spot in this limited space can sometimes ensue, just as in the case of image recording. To give an example of the intensity of the journalistic presence, there were more than twenty booms for Marine Le Pen's visit as a candidate, positioned at the exit of the cow show of the Salon on 28 February 2017 at 9.43am (fig. 1). In this example, the JRIs are not included as they have microphones positioned directly on their cameras and hence do not have a boom operator. Sound recording is essential for reporter/ editors. When it is impossible to pick up conversations when the boom is further than a metre or two away from the politicians, the boom or the microphone acts as a go-between that helps build their commentary. This same mechanism works for radio journalists who may not otherwise be able to comment on the politicians' speech. Media coverage of a visit is a true physical test that is reinforced during an election period. The visits often last seven hours, or fourteen hours and forty minutes for Emmanuel Macron's record presidential visit in 2019. And so the television teams hope to be relieved, but are very often active for the majority of the time. When the pursuing pack of journalists is big, this calls for attributes such as physical strength, and encourages exhibitions of fieldbased professional habitus. We return here to Loïc Wacquant's analysis of the pugilistic habitus and its effects on the body in 
Lorsque le groupe de journalistes suiviste est important, cela valorise des compétences comme la force physique et permet d'exhiber son habitus professionnel « de terrain ». On rejoint ici des analyses de Loïc Wacquant sur l'habitus pugillistique et ses effets en termes d'apprentissage sur le corps (Wacquant 2002). Or, à la différence du boxeur, le journaliste est communément pensé comme un travailleur intellectuel : on peine à le relier à une activité mettant en avant la condition physique. L'augmentation de la taille des groupes de journalistes qui suivent les politiques contribue de fait à viriliser les métiers de JRI et de photographe dont les statistiques soulignent le côté très masculin (Devillard et al. 2001, Leteinturier 2014), même si on note une féminisation récente dans les écoles de journalisme. Dans cette mêlée, la taille peut constituer un problème et un facteur également discriminant. C'est ce que ressentent bien une journaliste de APTVnews ou un journaliste de TF1 qui, interrogés à ce sujet, expriment alors le pouvoir inattendu des journalistes de grande taille (Herpin 2006) dans la prise d'images. Dans ces journées particulièrement éprouvantes, les périodes de rencontre des politiques au sein du Salon « invisible » avec les représentants du secteur constituent des pauses bienvenues pour les journalistes. terms of learning (Wacquant 2004). However, unlike the boxer, in the common meaning, the journalist is classically considered to be an intellectual worker, which means we struggle to associate the profession with an activity that above all requires physical fitness. The increase in the size of groups of journalists following the politicians indeed contributes to a masculinization of the roles of $\mathrm{JRI}$ and photographer: the statistics highlight the large male bias (Devillard et al. 200; Leteinturier 2014) despite a recent influx of female students into journalism schools. In this scrum, size may be a problem and an equally discriminating factor. This was the sentiment expressed by journalists we spoke to from APTVnews and TF1, who alluded to a sort of unexpected power of the tall journalists (Herpin 2006) when recording images. On these extremely tough days, the periods in which politicians meet with sector representatives within the invisible Salon constitute a welcome break for journalists.

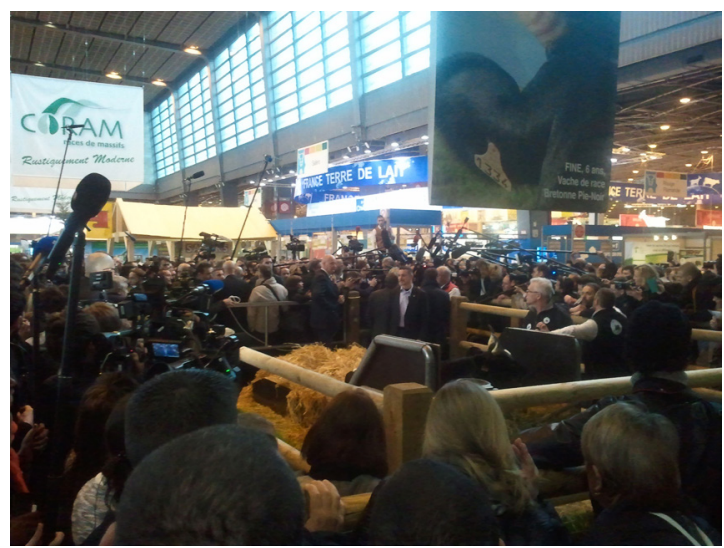

Fig. 1. Une intense présence journalistique (visite de la candidate Marine Le Pen, 28 février 2017) / A heavy media presence (candidate Marine Le Pen's visit, 28 February 2017) (c) Ivan Chupin et Pierre Mayance 


\subsection{Des stratégies des journalistes, entre coopération et}

évitement

Les visites produisent donc une lutte pour les places autour des politiques. Leur nombre limité et la dureté du métier poussent néanmoins les journalistes à coopérer ou à mettre en place des stratégies pour s'en sortir. Ainsi les journalistes, et en premier lieu ceux de la télévision, cherchent à s'organiser collectivement pour stabiliser et améliorer leurs conditions de travail. Le temps de mise en place précédant l'arrivée des politiques au Salon ou le temps de sortie d'un stand fermé ou d'une zone de repos sont fortement stratégiques. II s'agit alors, pour les cameramen et perchistes de la télévision et des autres médias, de se mettre en couloir, en ligne ou en arc de cercle afin que chacun puisse réaliser ce qu'il ou elle a à faire lors de l'apparition des politiques. On peut assister alors à des scènes irréelles - tout le monde est en place au bout du tapis rouge d'entrée à l'extérieur du Salon -, alors que le candidat E. Macron n'est pas encore arrivé (fig. 2).

En plus de ces accords collectifs tacites, réalisés dans les faits, les journalistes peuvent se monter plus actifs vis-à-vis des entourages des politiques. Le dispositif du point-presse est très souvent utilisé : par exemple, lors de la visite de en 2018 en tant que président des Républicains et de la région Auvergne-RhôneAlpes, Laurent Wauquiez ${ }^{24}$ tient un point à $10 \mathrm{~h} 10$ au milieu d'une allée du Salon (fig. 3). Devant l'absence d'un pool organisé et le constat d'un nombre trop important de journalistes qui entourent les politiques, d'autres journalistes demandent aux chargés de communication des politiques - et parfois même exigent - un pointpresse, comme ils ont pu le faire et l'obtenir lors de la visite du candidat Benoît Hamon en 2017. Dans ce cas, les journalistes sont

24. Laurent Wauquiez est alors président du parti gouvernemental de droite Les Républicains (décembre 2017-juin 2019). Ancien membre de gouvernements et député, il dirige le Conseil régional d’Auvergne-Rhône-Alpes depuis 2016.

\subsection{Journalist Strategies: Between Cooperation and Avoidance}

The visits therefore incite a battle for the spaces around the politicians. The limited number of these spaces and the harshness of the profession nevertheless drive journalists to cooperate or to implement a strategy to cope with the situation. Thus journalistsand primarily television journalists - seek to organize themselves collectively to stabilize and improve their working conditions. The moment of getting into position just before the politicians arrive at the Salon or as they leave a closed stand or a rest area is highly strategic. It involves the camera and boom operators for television and other media standing in a line or semi-circle, or forming two lines with a lane between them, in such a way that each can do what he or she needs to when the politicians arrive. We can see surreal scenes whereby everyone is in place at the end of the red carpet at the entrance to the Salon while candidate Emmanuel Macron is yet to arrive (fig. 2).

In addition to these tacit collective agreements carried out on the ground, journalists can be even more active when around the political entourages. The briefing system is frequently used, such as for Laurent Wauquiez's ${ }^{24}$ visit in 2018 as president of Les Républicains and of the Auvergne-Rhône-Alpes region, who held a session at 10.10am in the middle of an aisle of the Salon (fig. 3). With no pool organized and when they deem there to be too many journalists around the politicians, other journalists ask the communications officers for-or sometimes demand-a briefing, as they succeeded in doing during Benoît Hamon's candidacy visit in 2017. In this case the journalists are positioned in a semi-circle

24. Laurent Wauquiez was president of the right-wing governing party Les Republicains from December 2017 to June 2019. He is a former member of several governments and member of parliament, and has led the regional council of Auvergne-Rhône-Alpes since 2016. 

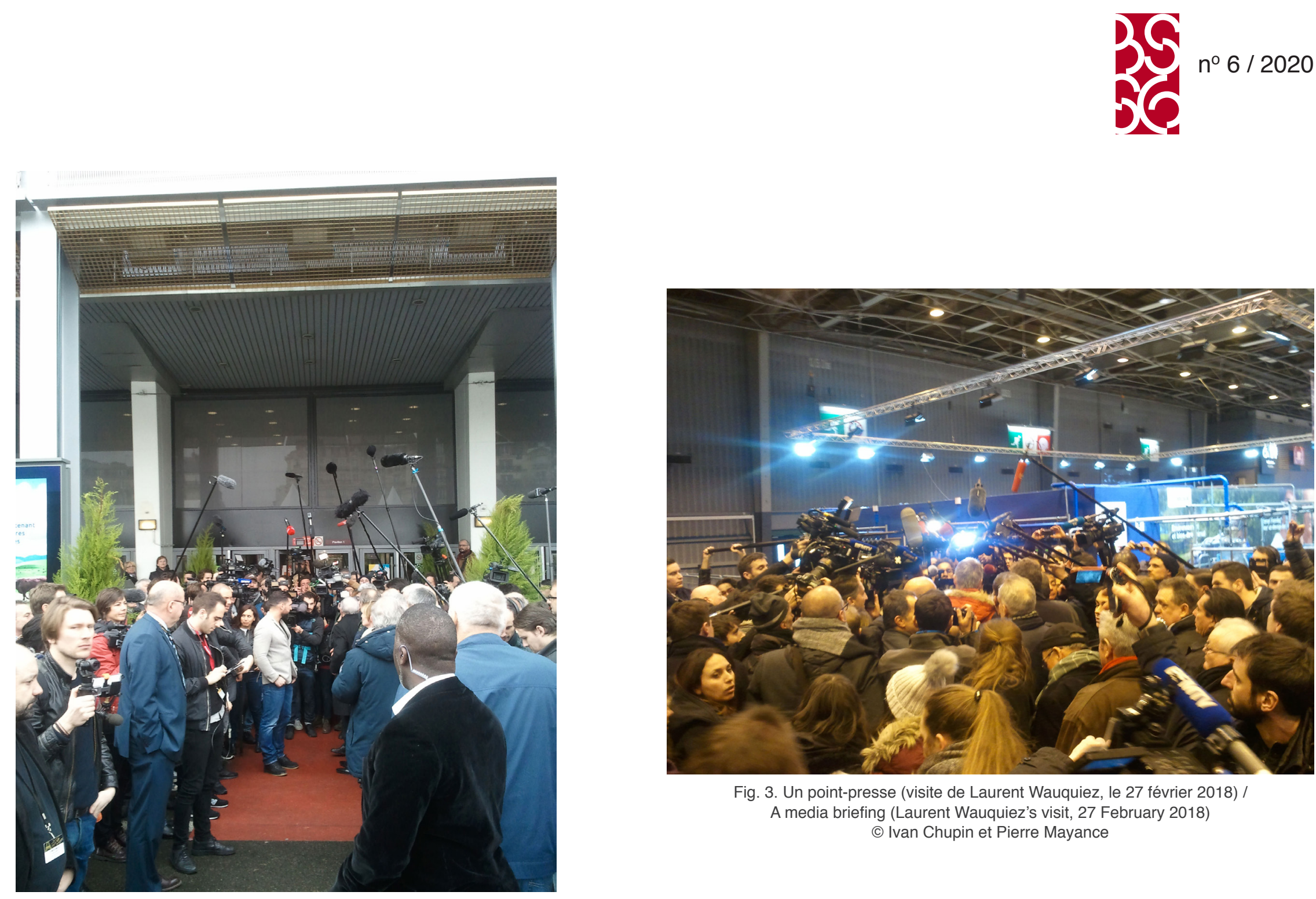

Fig. 3. Un point-presse (visite de Laurent Wauquiez, le 27 février 2018) / A media briefing (Laurent Wauquiez's visit, 27 February 2018) ( ) Ivan Chupin et Pierre Mayance

Fig. 2. En position d'attente des politiques

(visite du candidat Emmanuel Macron, $1^{\text {er }}$ mars 2017) / Awaiting the politicians

(candidate Emmanuel Macron's visit, 1 March 2017) (c) Ivan Chupin et Pierre Mayance 
positionnés en arc de cercle, face aux personnalités. Selon une durée variable s'échangent questions et réponses qui permettent à chacun de produire des images et du son. Les journalistes peuvent aussi s'appuyer sur les services d'ordre (SO) des partis qui ont un intérêt à ce que la visite se passe au mieux, dans un contexte où la généralisation des smartphones auprès du public rend aussi plus complexe la prise d'image. Les nombreux téléphones portables qui cherchent à filmer rentrent dans le cadre des JRI dont la prise de vue se voit ainsi parasitée. Cette proximité entre les politiques et le public est contrôlée par leur entourage et les services de sécurité. Un cas intéressant est celui du service d'ordre du candidat du Parti socialiste en 2017, B. Hamon. Constitué de militant·e.s, le SO est chargé d'une partie de la protection du candidat et en même temps organise l'accès à sa personne. Ainsi il forme une sorte de couloir au plus près du candidat pour qu'une personne du public puisse se rapprocher, prendre une photo et repartir de suite. C'est certes un angle perdu, mais les journalistes sont néanmoins libérés d'une certaine pression des quidams ainsi orientés dans ce flux. Le SO de Marine Le Pen permet aussi au public favorable à la candidate de venir prendre des photos avec elle.

Par ailleurs, les journalistes mettent en place des stratégies individuelles. Ils demandent régulièrement aux responsables de communication le programme de la visite, quand ils pensent faire une pause, quand ils sont censés repartir ainsi que leurs parcours afin d'anticiper leur positionnement. Comme le SIA se tient sur plus d'une semaine, certains font l'apprentissage des lieux et des routines d'organisation. Un rédacteur de TF1 suggère à son JRI : « II faut se mettre un stand à l'avance ${ }^{25}$. » Un journaliste de BFM conseille à un collègue : «Tu suis le mec au drapeau

25. Note de terrain, visite de M. Le Pen, 28 février 2017. opposite the politicians. Questions and answers are exchanged for a variable duration, allowing everyone to produce images and sound. Journalists can also rely on the security personnel of parties who have an interest in the smooth running of the visit in a context wherein the spread of smartphones among the public also makes capturing images more complicated. The many mobile phones seeking to obtain video footage impinge on the JRIs, interfering with their shooting. This proximity between politicians and the public is controlled by the politicians' entourage and the security services. One interesting case was that of Benoit Hamon's-the Socialist Party candidate in 2017-security personnel. A security detail made up of activists was responsible for protecting the candidate, and at the same time organized access to him. A form of corridor was thus formed near to the candidate to allow members of the public to approach him, take a photo, and then leave straight away. While this is a lost angle for journalists, it lowers the pressure on them from whomever is amid the flux. Marine Le Pen's security also allowed favourable members of the public to come up to take photos with the candidate.

Journalists also employ individual strategies. They regularly ask communications officers for the visit programme: when they expect to take a break; when they plan to leave; and their planned route, in order to be able to plan out their positioning. As the SIA is on for more than a week, some develop good knowledge of the site and organizational routines. A TF1 reporter suggests to their JRI: "You have to get one stand ahead 25 ." A BFM journalist advises a colleague: "Follow the event management flag guy ${ }^{26}$, let yourself

25. Field notes, M. Le Pen's visit, 28 February 2017.

26. By "event management flag," the journalist is referring to the rolled up map that certain members of the SIA event management team carry above their heads to indicate the path the group should follow through the aisles of the Salon 
du protocole ${ }^{26}$, tu te fais pousser sur un stand et comme ça tu auras une belle image $\mathrm{e}^{27}$. » Une autre stratégie consiste dans le fait de tourner des images en décalé avec le passage des politiques. Délaissant le groupe, les journalistes de télévision interviewent ceux et celles avec qui ils se sont entretenus. Ils refont d'une certaine manière l'échange tout en leur permettant de faire un sujet sur les réactions du public ou des agriculteurs. De manière quasi systématique dans le hall 1 , les éleveur·se·s sont invitée.e.s à réagir de manière répétée à leur rencontre avec les politiques, comme ce cas d'éleveurs du Limousin venant s'entretenir avec M. Le Pen au sujet de la politique agricole commune (fig. 4) : pour BFM, pendant cette visite de la candidate du Rassemblement bleu Marine, une équipe tourne en direct, et une autre interroge après coup les éleveurs qu'elle a rencontrés. be pushed up against a stand and you'll get a good shot that way ${ }^{27}$." Another strategy consists of filming images out of step with the politicians' movements. Abandoning the group, television journalists interview those whom the politicians have previously talked to. They re-enact the exchange, which allows them to portray the reactions of farmers or members of the public. In the main hall, farmers are asked almost systematically to react over and over again as they meet politicians, such as in the case of the farmers from Limousin who came to talk to Marine Le Pen on the subject of the Common Agricultural Policy (fig. 4). During the Rassemblement bleu Marine candidate's visit, one BFM team filmed live and another interviewed the farmers she had met previously.

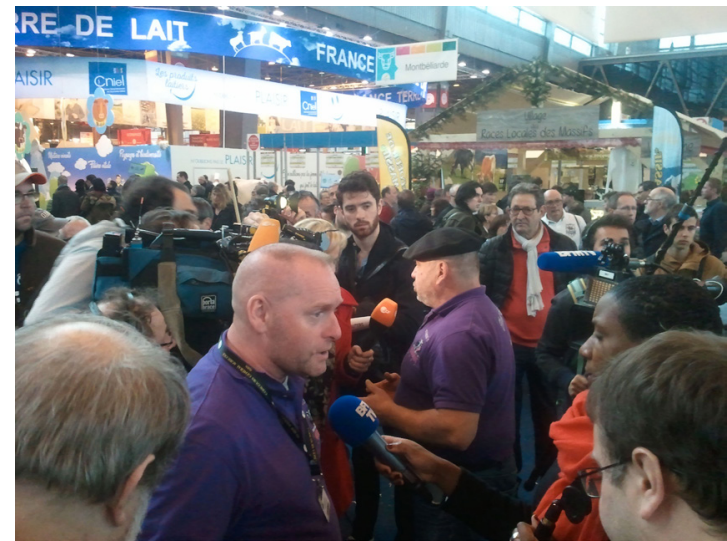

Fig 4. Des interviews après le passage des politiques (visite de la candidate Marine Le Pen, 28 février 2017) / Interviews following politicians' visit (candidate Marine Le Pen's visit, 28 February 2017)

(c) Ivan Chupin et Pierre Mayance

26. Ce que le journaliste désigne comme le « drapeau du protocole » fait référence au plan enroulé que certains membres du protocole du SIA tiennent au-dessus de leur tête afin de montrer le chemin que le groupe doit emprunter dans les allées du Salon.

27. Note de terrain, visites d'E. Macron et de F. Fillon, le $1^{\text {er }}$ mars 2017.

27. Field notes, visits by E. Macron and F. Fillon, 1 March 2017. 


\section{Nouvelles modalités de couverture télévisuelle des visites politiques}

\subsection{Un nouvel impératif : « La captation, c'est l'audience»}

Depuis quelques années, l'irruption des chaînes d'information en continu contribue à transformer les modalités concrètes de travail des journalistes de télévision. Ceux-ci doivent être présents et sur le qui-vive pour ne pas "louper "l'image" ", ce qui réduit d'autant leur autonomie professionnelle vis-à-vis du choix des sujets et de l'angle sous lequel ils sont traités. Ces injonctions à obtenir continuellement de l'image et du son proviennent des règles imposées au sein des chaînes d'information en continu, au sein desquelles il est demandé un direct au journaliste toutes les trente

minutes.

Cette tendance s'accroît aussi par l'évolution des moyens techniques. En effet, les images peuvent être à présent transmises en direct grâce aux boîtiers Aviwest qui permettent la compression de ces images avec le réseau cellulaire fourni par des clés $4 G$ (sauf en cas d'absence de signal téléphonique). Le boîtier peut transmettre presque en temps réel les images que le JRI tourne, ce qui a supprimé les personnels en charge des cars de transmission. L'usage des hautes fréquences pendant le SIA tient au fait que les équipes rédactionnelles anticipent la présence excessive de portables au même endroit, ce qui peut venir compliquer l'utilisation de la 4G. Cette transformation technologique a des effets importants sur le travail journalistique pour toutes les télévisions, comme le montre cette analyse d'un journaliste de TF1 :

« La baisse du temps de travail, c'est la baisse du journalisme. On fait de la captation, le journaliste en plateau raconte ce qui se passe à l'image. II faut être tout le temps partout au cas où. Si on ne l'a pas, ce n'est pas grave. Tu fais

\section{Innovations in TV Coverage of Politicians' Visits}

\subsection{New Rule: "Footage Means Viewers"}

In recent years, the explosion of channels providing continuous information has transformed the concrete working practices of television journalists. They must be present and vigilant so as not to "miss 'the image'," which at the same time reduces their professional autonomy vis-a-vis choice of subject and the angle the subject is approached from. These orders to continually obtain images and sound are a product of the rules imposed by continuous information channels, which require journalists to do a live broadcast every thirty minutes.

But the development of technology has also played a key role in the growth of this trend. Indeed, images can now be transmitted live with an Aviwest box, which compresses the images via 4G mobile phone networks (except in the absence of a mobile signal). The box can transmit the images captured by the JRIs almost in real time, which makes team members in charge of news-gathering vehicles redundant. The use of high frequencies at the SIA can be explained by the fact that the editorial teams anticipate a large number of mobile devices in one place, which can interfere with the use of $4 \mathrm{G}$. This technological transformation has had a major impact on journalistic work for all television channels:

"The reduction of working time means the reduction of journalism. We record footage; the journalist on the TV set narrates what is happening on screen. You have to be everywhere at all times just in case. If you don't get it, 
des planques au QG de Macron pour savoir ses éventuels soutiens. Mais si arrive le chef de cabinet, ou un député, le journaliste ne sait pas de qui il s'agit. II y a trois entrées, donc on met trois journalistes. On met une caméra pour faire de la captation. Le boulot de journaliste se fait hors actualité chaude. La captation, c'est l'audience. »

De manière contre-intuitive, l'imposition du direct vient commander de plus en plus en amont les angles sous lesquels les sujets sont traités. II conforte le pouvoir des rédactions en chef. Par exemple, un journaliste rédacteur de BFM doit expliquer dans son sujet « pourquoi la candidature de Benoit Hamon peine à décoller dans les sondages ». Le cadre est fortement contraint par les équipes éditoriales (Breed 1955, Berthaut 2013) qui décident en amont des hiérarchies entre les sujets mais aussi entre les candidats. Même pendant le tournage, les angles changent peu et sont déterminés à distance. Ces nouvelles pratiques laissent très peu de marges de manœuvre aux journalistes et constitue une rupture pour des journalistes télévisuels qui avaient parfois encore une relative capacité à déterminer et à proposer des angles à leur rédaction en lien avec les événements suivis. C'est aussi le statut même des images qui changent : les rushes tendent à disparaître au profit des inputs, le montage s'effectue en direct ${ }^{28}$. Ces logiques professionnelles de captation en continu des chaînes d'info sont liées pour les autres JRI à des questions de générations ou de formation. En 2017, un journaliste de TF1 note : « Je ne sais pas si c'est une question de génération, mais il y a un problème avec BFM. » La journaliste d'Aptv news répond : « lls ne sont pas formés

28. Les rushes désignent l'ensemble des séquences d'images tournées par les journalistes sur un reportage, images qui font ensuite l'objet d'un montage a posteriori. Les inputs désignent le flux d'images en continu qui sont diffusées en temps réel. Le montage s'effectue sur le choix des flux. never mind. You hide out at Macron's GHQ to learn who his potential support staff might be. But the chief of staff comes along, or a member of parliament, and the journalist doesn't know who it is. There are three entrances, so you send three journalists. You send a camera to record. The journalist's work is carried out away from the breaking news. Footage means viewers," analyses a TF1 journalist.

Counter-intuitively, the requirement to broadcast live means the angles subjects tackled are increasingly determined ahead of time. This increases the power of the editors-in-chief. For example, a BFM journalist must explain in their piece "why Benoit Hamon's candidature is struggling to take off in the polls." The framework is tightly constrained by editorial teams (Breed 1955, Berthaut 2013) who decide the hierarchies between subjects and also between candidates in advance. Even during filming, the angles change little and are determined at a distance. These new practices leave journalists very little room for manœuvre, and constitute a rupture for television journalists who still sometimes had relative capacity to determine and propose angles to their editorial team linked to the events they followed. There has also been a change to the very status of images: "rushes" have tended to disappear in favour of "inputs" with the editing done live ${ }^{28}$. The news channels' professional approaches to live recording are linked to generational and training issues for other JRIs. In 2017, a TF1 journalist remarked: “I don't know if it's a question of generation, but there's a problem with BFM." An Aptv news journalist responds: "They are not adequately trained. They film everything. They don't know what they need. They are under crazy pressure and so they're not trained properly."

28. "Rushes" refer to all sequences of images shot by journalists for one storyimages which are edited afterwards. "Inputs" refer to a continuous stream of images broadcast in real time. Editing is carried out in terms of choices within the stream. 
de manière adéquate. Ils filment tout. Ils ne savent pas ce dont ils ont besoin. Ils ont une pression de malade et, du coup, sont mal formés. " Le premier raconte le cas où il a dû mettre sa caméra sur celle d'un journaliste de BFM qui ne laissait pas sa place en l'écrasant pour pouvoir capter son image de manière propre ${ }^{29}$. II s'agit pourtant de nouvelles logiques de production des images provenant des chaînes d'information en continu qui impactent

l'ensemble des journalistes télévisuels et qui viennent transformer les normes professionnelles.

\subsection{Stratégies de communication politiques}

Les politiques ne sont pas démunis face à la mobilisation des journalistes télévisuels. On note en effet des stratégies multiples pour influencer la couverture des visites. À cette communication « grand public » s'ajoute celle adressée aux militants.

Le cas de la visite au Salon de l'agriculture nous donne à voir que les relations entre politiques et journalistes s'inscrivent dans un continuum $^{30}$ : entre un pool présidentiel où le politique contrôle le plus les journalistes et des cas de désintérêt médiatique pour des politiques qui se plient pourtant aux rituels. Le suivi médiatique est en effet inégalitaire. Le président de la République dispose d'un pool dit «présidentiel » qui est composé de journalistes seul·e·s autorisée.s à être au plus près lors de ses déplacements, excluant le reste de la profession renvoyé en dehors du système de sécurité. Un pool mélange donc un jeu d'accréditations supplémentaires ${ }^{31}$

29. Notes de terrain, venue de M. Le Pen, 28 février 2017.

30. Voir notamment le cas de l'annulation puis de la visite de F. Fillon lors des présidentielles de 2017 (Chupin \& Mayance 2018a).

31. En sociologie, l'accréditation de journalistes spécialisés et ses effets symboliques a bien été étudiée (Haegel 1992, Lévêque 1992, Marchetti, 2002)
The first describes a case in which he had to put his camera on top of that of a BFM journalist who would not budge from his spot, leaning down on it so that he could record the image the way he wanted ${ }^{29}$. Yet it is a question of new logics of image production that originate in twenty-four-hour news channels; they affect all television journalists and are transforming professional standards.

\subsection{Political Communication Strategies}

Politicians are not helpless in the face of the television journalists massive presence. Indeed we can observe multiple strategies to influence the coverage of visits. As well as their message to the general public, there is another directed at activists.

The case of visits to the SIA reveals that relations between politicians and journalists are part of a continuum ${ }^{30}$ : between a presidential "pool" whereby the politician is primarily in control of the journalists, and cases of media disinterest in politicians who nevertheless yield to the rituals. Media coverage is in effect unequal. The French president has access to a so-called "presidential" pool composed of the only journalists authorized to follow him closely, excluding the remainder of the profession who are kept outside the security system. A pool therefore mixes a set of extra accreditations ${ }^{31}$ with phenomena of cooperation that are imposed in a television

29. Field notes, M. Le Pen's visit, 28 February 2017.

30. See in particular the case of the cancellation followed by the visit by François Fillon during the 2017 election campaign (Chupin \& Mayance 2018a).

31. The accreditation of specialist journalists and its symbolic effects has indeed been studied studied in sociology (Haegel 1992, Lévêque 1992, Marchett 2004). 
avec des phénomènes de coopérations imposées dans un univers télévisuel pourtant très concurrentiel (Bourdieu 1996). II implique une mutualisation des productions journalistiques (images, sons, photos, notamment) des accréditéee.s en direction du reste du groupe professionnel. La taille du pool a été réduite sous la nouvelle présidence d'E. Macron. Dans le pool de télévision, seul.e.s des journalistes de TF1 et de France 2 sont autorisé e-s à le suivre. Ils et elles portent, comme leurs confrères en 2017, des chasubles bleues avec le sigle « presse » ou des brassards bleus « pool » sous E. Macron en 2018 et 2019. Cela permet l'identification rapide, par les services d'ordre, des journalistes habilité·e·s à être (ou non) présent·e.s dans le cercle rapproché du président de la République. Le président bénéficie de forces de l'ordre dédiées, le groupement de sécurité de la présidence de la République (GSPR) auxquelles s'ajoutent des $\mathrm{CRS}^{32}$, des gendarmes, des policiers des arrondissements proches ou de la préfecture de police de Paris ${ }^{33}$. À l'autre bout du continuum, la couverture vient redoubler médiatiquement des inégalités de notoriété dans le champ politique, selon un processus bien connu (Darras, 1995). En effet, peu nombreux sont les candidats en 2017 qui ont droit à un sujet dédié à leur passage dans le cadre du journal télévisé : sont ainsi exclus les candidats jugés comme secondaires car notés comme faibles dans les intentions de vote dans les sondages: François Asselineau (Union Populaire Républicaine), Jean Lasalle (Résistons !), Jacques Cheminade (Solidarité et Progrès), Philippe Poutou (Nouveau Parti Anticapitaliste), Nicolas Dupont-Aignan (Debout la République) ou Rama Yade (La France qui ose).

32. En France, les Compagnies républicaines de sécurité (CRS) sont des policiers spécialisés dans le maintien de l'ordre. Elles sont notamment mobilisées lors des manifestations et des conflits sociaux.

33. Sur instruction du ministère de l'Intérieur, d'autres candidats bénéficient également d'une protection rapprochée, notamment en période électorale (M. Le Pen, E. Macron, F. Fillon, B. Hamon, J.-L. Mélenchon en 2017). universe that is, however, highly competitive (Bourdieu 1998). It involves a pooling of journalistic productions (recorded images, sound, photographs, etc.) by accredited journalists for the benefit of the rest of the professional group. The size of the pool has been reduced under Emmanuel Macron's presidency. In the television pool, only TF1 and France 2 journalists are authorized to follow the president. Under Macron in 2018 and 2019, they wear blue vests that say "press," or blue "pool" wristbands as their 2017 colleagues did. This allows them to be quickly identified by security personnel so that they know which journalists are supposed (or not) to be present within the close circle of the president of the Republic. The president is also protected by dedicated law enforcement forcesthe security group of the presidency of the Republic (GSPR) - plus the Compagnies républicaines de sécurite $(C R S)^{32}$, gendarmes, and police officers from the closest arrondissements and the Paris Police Prefecture ${ }^{33}$. At the other end of the continuum, the coverage amplifies disparity of reputation in the political field according to a well-known process (Darras 1995). Indeed, there were few candidates in 2017 whose journey was deemed worthy of featuring on the news: the following candidates, considered to be second class owing to their low ratings in voting intention surveys, were thus excluded: François Asselineau (Union populaire républicaine), Jean Lasalle (Résistons!), Jacques Cheminade (Solidarité et progrès), Philippe Poutou (Nouveau Parti Anticapitaliste), Nicolas Dupont-Aignan (Debout la République), and Rama Yade (La France qui ose).

32. The Compagnies républicaines de sécurité (CRS) are specialized law enforcement police officers. They are mobilized primarily for demonstrations and social conflicts.

33. On the instruction of the Ministry of the Interior, other candidates also benefit from close protection, especially during an election period (M. Le Pen, E. Macron, F. Fillon, B. Hamon, and J.-L. Mélenchon in 2017). 
Les politiques et leur entourage déploient un certain nombre de stratégies pour contrôler leur image. Le poolconstitue une réduction du risque symbolique encouru par les présidents. E. Macron, candidat en 2017, avait reçu un œuf lancé par quelqu'un du public. Présent en même temps que F. Fillon en visite houleuse le jour de la convocation chez le juge (Chupin \& Mayance 2018), il bénéficiait d'une moindre présence de journalistes et de la sécurité. De retour en 2018 en tant que président, on assiste à un renforcement du rôle du pool et du contrôle des images. Le déploiement des forces de l'ordre est massif. En plus des services rapprochés, il est accompagné de plus de deux-cent-cinquante policiers, qui se déploient en fin de matinée après les premiers accrochages avec des représentants syndicaux agricoles qui troublent sa visite avec des sifflets. En 2019, le dispositif est mis en œuvre dès son arrivée au Salon pour sa visite record de 14h40. En plus du premier cordon de sécurité qui limite l'accès aux journalistes accrédités du pool, un deuxième cordon est mis en place. Les journalistes de télévision hors pool sont éloignés plus que d'habitude du groupe présidentiel, et sont donc mis dans une impossibilité matérielle de tourner des images du président, rompant l'accord tacite de publicité entre le chef de l'État et les médias. En 2018, alors que les policiers repoussent les caméras, un JRI les interpelle : « Il y a trop de com', il y a une trop grosse bulle [no man's land entre les deux cordons de sécurité]. Ce n'est pas bon de détourner les journalistes qui vont aller ailleurs. ${ }^{34}$ » II est pourtant condamné à rester au cas où. En pratique, les seules images disponibles sont majoritairement celles produites par le pool, uniformisant ainsi la couverture médiatique télévisuelle.

34. Note de terrain, visite d'E. Macron, 24 février 2018.
The politicians and their entourage deploy certain strategies to control their image. The pool constitutes a reduction of the symbolic risk incurred by presidents. A member of the public threw an egg at Emmanuel Macron when he was a candidate in 2017. His visit coincided with a turbulent visit by François Fillon on the day he was summoned to a court hearing for embezzlement of public funds (Chupin \& Mayance 2018), and so there were few journalists and security around Macron. When he returned in 2018 as president there was a reinforcement of the role of the pool and of the control of images. The deployment of law enforcement officers was huge. As well as the close protection, there were more than 250 police officers, who were deployed at the end of the morning after the first clashes with representatives from agricultural trade unions who disrupted the visit by blowing whistles. In 2019 , this system was put in place from the start of his record 14 hours 40 minutes long visit to the SIA. As well as the first security cordon which limited access to accredited journalists from the pool, a second cordon was implemented. Television journalists who were not in the pool were even further away than usual from the presidential group, and were therefore physically unable to film the president; the tacit publicity agreement between the head of state and the media was broken. In 2018, when police officers pushed back the camera operators, one JRI called out: "There're too many PRs, there's a trop grosse bulle [no man's land between the two security cordons]. It's not good to turn journalists away-they'll go elsewhere ${ }^{34}$." However they were obliged to remain where they were just in case something happened. In practice, the only images available are predominantly those produced by the pool, thus homogenizing the televised media coverage.

34. Field notes, E. Macron's visit, 24 February 2018. 
Finalement, cet encadrement par les services de protection rend possible une mise en scène de la proximité alors que, paradoxalement, personne (de non autorisé) ne peut, dans les faits, accéder au président. Les journalistes du pool saisissent ainsi en live les interactions en apparence spontanées du président de la République et peuvent retenir dans leur commentaire le fait qu'il va « au-devant des gens ordinaires » ou « à la rencontre des agriculteur.rice.s ». Il pose en photo avec des enfants, se laisse embrasser, serre des mains. Le cadrage sur le risque symbolique de sa visite tenu le matin même en 2018 sur BFM apparaît donc comme largement construit. Les opposantee.s peuvent très difficilement l'approcher. De plus, pour limiter ce risque, le président de la République est venu le matin avec une trentaine de supporters afin de le soutenir en «faisant la claque ${ }^{35}$ ». Ils et elles sont à nouveau présent $\cdot e \cdot s$ en 2019 . Se réunissant près de la porte de Versailles, on leur distribue des places pour rentrer au Salon. Ils et elles se positionnent au plus proche du président en tant que " public » et l'accompagnent dans une grande partie de sa visite, applaudissant ou criant «Macron, tiens bon ! ». E. Macron peut ainsi battre sans grande adversité le record de présence au Salon en y restant plus de douze heures en 2018.

Par leur abondance, notamment lorsque plusieurs équipes opèrent pour un même média, les journalistes sont poussés à se reporter sur les périphéries du cortège. Les mouvements politiques fournissent alors à travers les supporters élu.e.s ou les militant·e.s des occasions de réaliser des images et des sons avec ces doublures des têtes d'affiche. C'est le cas, pendant la visite de M. Le Pen le 28 février 2017, de Marion Maréchal Le Pen, à une dizaine de mètres de la candidate et hors du premier cercle des

35. On retrouve des techniques anciennes, mises au jour par N. Mariot, 2006.
Finally, this encircling by protection officers enables a show of proximity; whereas, paradoxically, in reality no one (unless authorized) can gain access to the president. The pool journalists thus capture the seemingly spontaneous interactions of the French president live and can state in their commentary that he has had contact with "ordinary people," or has "met farmers." He poses for a photo with children, allows himself to be hugged, shakes hands. The focus on the symbolic risk of his visit which took place the same morning in 2018 on BFM therefore appears as primarily staged. Opponents could not easily approach him. Additionally, to limit this risk, the president arrived in the morning with around thirty supporters to cheer him on ${ }^{35}$. They were there again in 2019. After assembling near the porte de Versailles they were given passes to get into the SIA. They positioned themselves nearest the president as "the public" and accompanied him for most of his visit, clapping and shouting "Macron, tiens bon!' ("Macron, hold on!"). Emmanuel Macron was thus comfortably able to beat the record for time spent at the SIA by staying more than twelve hours in 2018 .

The abundance of journalists, especially when there are several teams per media, forces them to keep to the edge of the cortège. Political movements therefore provide, via selected supporters or activists, opportunities to get images and sound recordings of stand-ins for the top names. This happened during Marine Le Pen's visit on 28 February 2017 with Marion Maréchal Le Pen, who was standing about ten metres from the candidate and outside the first circle of journalists (fig. 5) ${ }^{36}$. Thanks to the unexpected

35. We observe long-running techniques highlighted by N. Mariot, 2006.

36. In 2019, this role was played by Thierry Mariani (formerly of Rassemblement pour la République, Union pour un mouvement populaire, and Les 
journalistes (fig. 5) ${ }^{36}$. La présence inattendue d'autres politiques permet aux JRI de proposer d'autres sujets, et à ces politiques d'intervenir à distance dans un échange de petites phrases avec les personnalités dont la visite était prévue. Ainsi la mise en place de la double nasse autour du président E. Macron en février 2018 a favorisé une certaine dispersion des journalistes, dont certains sont tombés sur le député de la France insoumise Alexis Corbière en visite au Salon avec sa famille.

Enfin, les politiques organisent leur communication grâce à mais aussi pour leurs militant·e.s. Lors des présidentielles de 2017, les petits candidats tentent d'exister médiatiquement. François Asselineau, peu connu à l'époque dans les grands médias ${ }^{37}$, réalise sa visite le premier jour du Salon. Bien que seul candidat présent le samedi ( $F$. Hollande, le président sortant est présent la matinée), il n'est suivi par aucun journaliste. Les seuls preneurs d'image et de son qui le suivent sont deux militants de son mouvement qui le filment. La présence de ces caméras interpelle plusieurs personnes parmi le public du Salon qui, à son passage, se demandent qui il est. J. Cheminade est également peu suivi par des journalistes, hormis ceux (Public Sénat, une équipe de France 3) qui ont pour objectif alors de réaliser un sujet sous l'angle des « petits candidats en campagne » en 2017. Plus généralement, l'entourage des politiques produit des photos, parfois des sons et des images qui servent à alimenter les outils numériques (site dédié, YouTube, Twitter, etc.) tant en période ordinaire qu'en période de campagne (Greffet 2011). Ils fournissent ainsi de l'information aux journalistes,

36. En 2019, ce rôle est joué par Thierry Mariani (ancien RPR-UMP-LR) qui a rejoint la liste européenne du Rassemblement national (RN) en position éligible.

37. II ne dispose pas encore des 500 signatures et n'a pas participé au débat avec les autres candidats. presence of other politicians, the JRls are able to choose alternative subjects to film, and these politicians can intervene remotely in a quick exchange with the politicians the visit was planned for. Thus the establishment of the double net around President Macron in February 2018 pushed some journalists out of the way, causing several to fall onto Alexis Corbière, member of parliament for La France insoumise who was visiting the SIA with his family.

Finally, politicians organize their PR thanks to, but also for their activists. During the 2017 presidential election campaign, the minor candidates attempted to have a media presence. François Asselineau, who was little known in the main media at the time ${ }^{37}$, visited the SIA on the first day. Despite being the only candidate there on the Saturday (François Hollande, the outgoing president, was there in the morning), he was not followed by a single journalist. The only ones to get video and sound recordings were two activists who followed and filmed him. The presence of these cameras caught the attention of several members of the public at the Salon, who wondered who he was as he went by. Jacques Cheminade also received little attention from journalists, except those from the Public Sénat channel and team from the France 3 channel, who were doing a feature on "minor candidates' campaigns" in 2017. More broadly, politicians' entourages produce photographs, and sometimes sound and images which serve to fuel digital tools (dedicated websites, YouTube, Twitter, etc.) both during ordinary periods and election campaigns (Greffet 2011). They thereby

Républicains), who joined the National Rally's European list as a candidate.

37. He did not, at the time, have the five hundred signed endorsements from elected officials, which are required to compete in the French presidentia campaign, and therefore he had not participated in any debate with other candidates. 
mais aussi à leurs militant·e.s et soutiens qui peuvent suivre l'activité des politiques. provide information to journalists, but also to their activists and supporters so that they may follow politicians' activity.

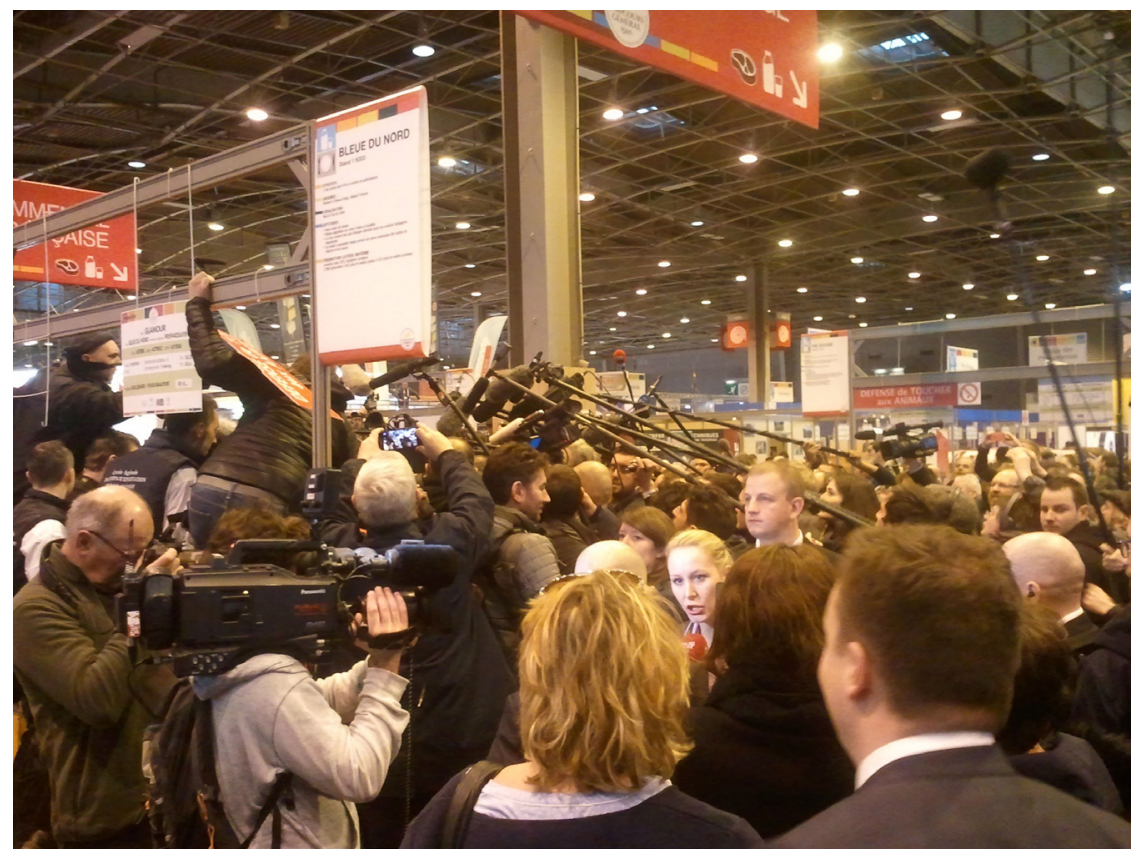

Fig. 5. Cohue sur la candidate et interview en parallèle de Marion Maréchal (visite de la candidate Marine Le Pen, 28 février 2017) A scrum surrounding the candidate and parallel interview with Marion Maréchal (candidate Marine Le Pen's visit, 28 February 2017)

(c) Ivan Chupin et Pierre Mayance

\section{Conclusion}

Les visites du Salon permettent d'appréhender l'importance d'un événement politique en termes de production collective. Le groupe de la visite est le résultat d'une coproduction entre les organisateur.rice's du Salon de l'agriculture, les journalistes, les 
services d'ordre et les communicant·e's des politiques. Sous sa forme la plus organisée, elle se dénomme pool, mais le suivi journalistique plus ordinaire n'est pas dénué pour autant de codes.

S'il n'y a pas tellement de différences entre les images médiatiques produites, c'est notamment parce que ces biens symboliques dépendent d'un sens pratique journalistique activé en temps réel et de commandes éditoriales. Le cadrage reste surdéterminé par la forme de la visite au Salon. La contrainte de l'immédiateté s'impose dans les pratiques et les corps des journalistes de télévision et s'étend aux autres médias. Cette contrainte est aussi intégrée par les politiques et leurs entourages.

Cet article renseigne sur le traitement de la campagne électorale et des nouveaux contrôles de la médiatisation. De ce point de vue, il contribue à l'étude des formes ritualisées de la vie politique. I participe également à l'analyse de la transformation des conditions de travail journalistiques, plus intenses et désormais soumises au mode continu de l'information. En effet, ce cas permet de questionner l'émergence d'un modèle de journaliste-animateur en direct qui tend à s'imposer à l'ensemble du champ journalistique sous l'effet de la récente hégémonie des nouvelles chaînes d'information en continu (BFM, notamment). Si la littérature se concentre le plus souvent sur l'étude de Twitter et du journalisme en ligne, cet article entend souligner tout l'intérêt de travailler à une ethnographie du travail journalistique sur le terrain, hors des salles

de rédaction.

Ivan Chupin

Université de Versailles Saint-Quentin-en-Yvelines Professions, institutions, temporalités (Printemps)

Pierre Mayance

Université Paris 1 - Centre européen de sociologie et de science politique its most organized form, it is called a "pool," but regular media attention is not, however, without its own codes.

While there are no real differences between the media images produced, this is mainly since these symbolic goods depend on a practical, journalistic meaning activated in real time and on editorial demands. The media angle remains overdetermined by the form of the SIA visit. The constraint of immediacy is imposed by the practices and the body of television journalists, and extends to other media. This constraint has also been assumed by politicians and their entourages.

This article provides insight into the handling of election campaigns and new ways of harnessing and controlling media coverage. From this perspective it contributes to the study of ritualized forms of political life. It also engages in analysis of journalistic working conditions, which have been transformed by twenty-four-hour news and the intensification of the work. Indeed, this case invites us to question the emergence of a model of live journalist-presenter that is becoming ubiquitous throughout the journalistic field under the effect of the recent hegemony of new twenty-four-hour news channels (BFM in particular). While the literature focuses on the study of Twitter and online journalism, this article aims to highlight all the merits of working on an in-the-field ethnography of journalistic work outside the newsroom.

Ivan Chupin Université de Versailles Saint-Quentin-en-Yvelines Professions, institutions, temporalités (Printemps) Pierre Mayance Université Paris 1 - Centre européen de sociologie et de science politique ( $\underline{\text { Cessp }})$ 


\section{Références bibliographiques}

BaAmara Layla, Floderer Camille, Poirier Marine (dir.) (2017). Faire campagne, ici et ailleurs : mobilisations électorales et pratiques politiques ordinaires. Paris, Karthala.

BAISNÉE Olivier \& MARChETTI Dominique (2002). « L'économie de l'information en continu. À propos des conditions de production dans les chaînes d'information en général et à Euronews en particulier ». Réseaux, $114: 181-214$

Berthaut Jérome (2013). La Banlieue du « 20 heures ». Ethnographie d'un lieu commun journalistique. Marseille, Agone.

Boczkowskı Pablo J. (2004). Digitizing the News : Innovation in Online Newspapers. Cambridge, MIT Press.

Boczkowski Pablo J. (2015). « The Material Turn in the Study of Journalism : Some Hopeful and Cautionary Remarks from an Early Explorer ». Journalism, 16(1) : 65-68.

BoczKowski Pablo J. \& ANDERSON Christopher William (dir.) (2017). Remaking the News Essays on the Future of Journalism Scholarship in the Digital Age. Cumberland, MIT Press.

BOURDieu Pierre (1996). Sur la télévision. Paris, Seuil.

BREED Warren (1955). «Social Control in the Newsroom : A Functional Analysis ». Social Forces, 33(4) : 326-335.

CotTle Simon (2000). «New(s) Times : Towards a "Second Wave" of News Ethnography ». Communications, 25(1) : 19-41.

Champagne Patrick (1990). Faire l'opinion : le nouveau jeu politique. Paris, Minuit.

Charon Jean-Marie \& Mercier Arnaud (dir.) (2004). Armes de communication massives. Informations de guerre en Irak, 1991-2013. Paris, CNRS éditions.

\section{References}

BaAmara Layla, Floderer Camille, Poirier Marine (eds.) (2017). Faire campagne, ici et ailleurs: mobilisations électorales et pratiques politiques ordinaires. Paris, Karthala.

BAISnÉE Olivier \& MARChETTI Dominique (2006). "The Economy of Justin-Time Television Newscasting: Journalistic Production and Professiona Excellence at Euronews." English translation by Fredline Larea. Ethnography, 7(1): 99-123.

Berthaut Jérome (2013). La Banlieue du "20 heures". Ethnographie d'un lieu commun journalistique. Marseille, Agone.

Boczkowskı Pablo J. (2004). Digitizing the News: Innovation in Online Newspapers. Cambridge, MIT Press.

Boczkowskı Pablo J. (2015). "The Material Turn in the Study of Journalism: Some Hopeful and Cautionary Remarks from an Early Explorer." Journalism, 16(1): 65-68.

Boczkowski Pablo J. \& ANDERSON Christopher William (eds.) (2017). Remaking the News Essays on the Future of Journalism Scholarship in the Digital Age. Cumberland, MIT Press.

BOURDIEU Pierre (1998). On Television and Journalism. English translation by Priscilla Parkhurst Ferguson. London, Pluto.

Breed Warren (1955). "Social Control in the Newsroom: A Functional Analysis." Social Forces, 33(4): 326-335.

CotTle Simon (2000). "New(s) Times: Towards a 'Second Wave' of News Ethnography." Communications, 25(1): 19-41.

Champagne Patrick (1990). Faire l'opinion: le nouveau jeu politique. Paris, Minuit.

Charon Jean-Marie \& Mercier Arnaud (eds.) (2004). Armes de communication massives. Informations de guerre en Irak, 1991-2013. Paris, CNRS éditions. 
Chupin Ivan \& Mayance Pierre (2018a). «Quand le temps politique s'impose au temps médiatique. La visite du candidat F. Fillon au Salon international de l'agriculture ». In MARREL Guillaume \& PAYRE Renaud (dir.), Temporalité politique. Le temps dans l'action politique. Louvain-laNeuve, De Boeck : 71-84.

Chupin Ivan \& MAYANCE Pierre (2018b). « Des rencontres discrètes. Journalistes, politiques et groupes d'intérêt au Salon international de l'agriculture ». Savoir/Agir, $46: 75-81$.

Christin Angèle (2014). Between Clicks and Pulitzers : Web Journalists and their Work in the United States and France. Thèse de doctorat en sociologie. Princeton, Princeton University.

DARRAS Éric (1995). « Le pouvoir "médiacratique" ? Les logiques du recrutement des invités politiques à la télévision ». Politix, $30:$ 83-198.

DeVIlLard Valérie, Lafosse Marie-Françoise, Leteinturier Christine, RiefFEL Rémy (2001). Les Journalistes français à l'aube de l'an 2000. Profils et parcours. Paris, Éditions Panthéon-Assas.

DuHAMEL Olivier \& FIELD Michel (2005). Le Starkozysme. Paris, Seuil.

Gans Herbert J. (1979). Deciding What's News : A Study of CBS Evening News, NBC Nightly News, Newsweek, and Time. New York, Pantheon.

GATIEN Emmanuelle (2009). « "Un peu comme la pluie”. La co-production relative de la valeur d'information en temps de guerre ». Réseaux, 157$158: 61-88$

Gerstlé Jacques \& PIAR Christophe (2016). La Communication politique. Paris, Armand Colin

GREFFET Fabienne (2011). Continuerlalutte.com. Les partis politiques sur le web. Paris, Presses de Sciences-Po.

HAEGEL Florence (1992). "Des journalistes "pris" dans leur source. Les accrédités à l'Hôtel de Ville de Paris, Abstract ». Politix, 19 : 102-119.

Herpin Nicolas (2006). Le Pouvoir des grands. Paris, La Découverte.
ChupIn Ivan \& MAYANCE Pierre (2018a). "Quand le temps politique s'impose au temps médiatique. La visite du candidat F. Fillon au Salon international de l'agriculture." In MARREL Guillaume \& PAYRE Renaud (eds.), Temporalité politique. Le temps dans l'action politique. Louvain-laNeuve, De Boeck: 71-84.

Chupin Ivan \& MAYANCE Pierre (2018b). "Des rencontres discrètes. Journalistes, politiques et groupes d'intérêt au Salon international de l'agriculture." Savoir/Agir, 46: 75-81.

CHRISTIN Angèle (2014). Between Clicks and Pulitzers: Web Journalists and Their Work in the United States and France. PhD Thesis, Sociology. Princeton, Princeton University.

DARRAS Éric (1995). "Le pouvoir 'médiacratique’? Les logiques du recrutement des invités politiques à la télévision." Politix, 30: 83-198.

DeVILlaRd Valérie, LAFOSSE Marie-Françoise, LeTEINTURIER Christine, RiefFel Rémy (2001). Les Journalistes français à l'aube de l'an 2000. Profils et parcours. Paris, Éditions Panthéon-Assas.

Duhamel Olivier \& FIELd Michel (2005). Le Starkozysme. Paris, Seuil.

Gans Herbert J. (1979). Deciding What's News: A Study of CBS Evening News, NBC Nightly News, Newsweek, and Time. New York, Pantheon.

Gatien Emmanuelle (2009). "'Un peu comme la pluie'. La co-production relative de la valeur d'information en temps de guerre." Réseaux, 157158: $61-88$.

Gerstlé Jacques \& PIAR Christophe (2016). La Communication politique. Paris, Armand Colin.

GREFFET Fabienne (2011). Continuerlalutte.com. Les partis politiques sur le web. Paris, Presses de Sciences-Po.

HAEGEL Florence (1992). "Des journalistes 'pris' dans leur source. Les accrédités à l'Hôtel de Ville de Paris, Abstract." Politix, 19: 102-119.

Herpin Nicolas (2006). Le Pouvoir des grands. Paris, La Découverte. 
HuBÉ Nicolas (2008). Décrocher la une. Le choix des titres de première page de la presse quotidienne en France et en Allemagne (1945-2005). Strasbourg, Presses universitaires de Strasbourg.

Kaciaf Nicolas (2013). Les Pages « Politique ». Histoire du journalisme politique dans la presse française (1945-2006). Rennes, Presses universitaires de Rennes.

LegaVRE Jean-Baptiste (1992). « "Off the record". Mode d'emploi d'un instrument de coordination ». Politix, $19: 135-158$.

LEGAVRE Jean-Baptiste (2011). « Entre conflit et coopération. Les journalistes et les communicants comme "associés rivaux" 》. Communications et langage, $169: 105-123$.

LETEINTURIER Christine (2014). Les Journalistes français et leur environnement. Le cas de la presse d'information générale et politique. Paris, Éditions Panthéon-Assas.

LÉVÊQUE Sandrine (1992). "La conférence de presse. Les transactions entre syndicalistes et journalistes sociaux ». Politix, $19: 120-134$.

LINDNER Andrew M. (2009). «Among the Troops : Seeing the Iraq War Through Three Journalistic Vantage Points ». Social Problems, 56(1) : 21-48.

Mac LaUghlin Greg (2016) [2002]. The War Correspondent. Chicago, Pluto Press.

MARCHETTI Dominique (2002). « Les sous-champs spécialisés du journalisme ». Réseaux, $111: 22-55$.

MARIOT Nicolas (2006). Bains de foule : les voyages présidentiels en province, 1888-2002. Paris, Belin.

MARIOT Nicolas (2007). C'est en marchant qu'on devient président. La République et ses chefs de l'État, 1848-2007. Montreuil, Aux lieux d'être.

MiLle Muriel (2016). « Le processus collectif de création d'un feuilleton télévisé ». Sociétés contemporaines, $101:$ :91-114.
Hubé Nicolas (2008). Décrocher la une. Le choix des titres de première page de la presse quotidienne en France et en Allemagne (1945-2005). Strasbourg, Presses universitaires de Strasbourg.

Kaciaf Nicolas (2013). Les Pages "Politique". Histoire du journalisme politique dans la presse française (1945-2006). Rennes, Presses universitaires de Rennes.

Legavre Jean-Baptiste (1992). “'Off the record'. Mode d'emploi d'un instrument de coordination." Politix, 19: 135-158.

LEGAVRE Jean-Baptiste (2011). "Entre conflit et coopération. Les journalistes et les communicants comme 'associés rivaux'." Communications et langage, 169: 105-123.

LETEINTURIER Christine (2014). Les Journalistes français et leur environnement. Le cas de la presse d'information générale et politique. Paris, Éditions Panthéon-Assas.

LÉVÊQUE Sandrine (1992). "La conférence de presse. Les transactions entre syndicalistes et journalistes sociaux." Politix, 19: 120-134.

LINDNER Andrew M. (2009). "Among the Troops: Seeing the Iraq War Through Three Journalistic Vantage Points." Social Problems, 56(1): 2148.

Mac Laughlin Greg (2016) [2002]. The War Correspondent. Chicago, Pluto Press.

MARCHETTI Dominique (2004). "Sub-Fields of Specialized Journalism." In Benson Rodney \& NeVEu Erik (eds.), Bourdieu and the Journalistic Field. Cambridge, Polity: 64-82.

MARIOT Nicolas (2006). Bains de foule: les voyages présidentiels en province, 1888-2002. Paris, Belin

MARIOT Nicolas (2007). C'est en marchant qu'on devient président. La République et ses chefs de l'État, 1848-2007. Montreuil, Aux lieux d'être.

MiLle Muriel (2016). "Le processus collectif de création d'un feuilleton télévisé." Sociétés contemporaines, 101: 91-114. 
NeVEu Erik (2009). Sociologie du journalisme. Paris, La Découverte.

PAsquier Dominique (2008). « Conflits professionnels et luttes pour la visibilité à la télévision française ». Ethnologie française, 38 : 23-30.

SCHLEsInger Philip (1978). Putting « Reality 》 Together : BBC News. Londres, Constable.

SIRACUSA Jacques (2001). Le JT, machine à décrire. Sociologie du travail des reporters de télévision. Bruxelles, De Boeck.

TUCHMAN Gaye. (1973). "Making News by Doing Work : Routinizing the Unexpected ». American Journal of Sociology, 79(1) : 110-131.

TUNTSTALL Jeremy (1971). Journalists at Work. Londres, Constable.

WACQUANT Loïc (2002). Corps et âmes, carnets ethnographiques d'un apprenti boxeur. Marseille, Agone.

WARNER Malcolm (1971). " Organisational context and control of policy in the television newsroom : A participant observation study ». British Journal of Sociology, 22(3) : 283-294.
NeVEU Erik (2009). Sociologie du journalisme. Paris, La Découverte.

PASQUIER Dominique (2008). "Conflits professionnels et luttes pour la visibilité à la télévision française." Ethnologie française, 38: 23-30.

SCHLEsinger Philip (1978). Putting "Reality " Together: BBC News. London, Constable.

SIRACUSA Jacques (2001). Le JT, machine à décrire. Sociologie du travail des reporters de télévision. Bruxelles, De Boeck.

TuCHmAN Gaye. (1973). "Making News by Doing Work: Routinizing the Unexpected." American Journal of Sociology, 79(1): 110-131.

TUNTSTALL Jeremy (1971). Journalists at Work. London, Constable.

WaCQUANT Loïc (2004). Body and Soul: Notebooks of an Apprentice Boxer. Oxford University Press.

WARNeR Malcolm (1971). "Organisational Context and Control of Policy in the Television Newsroom: A Participant Observation Study." British Journal of Sociology, 22(3): 283-294. 